\title{
The Informational Role of the Media in Private Lending
}

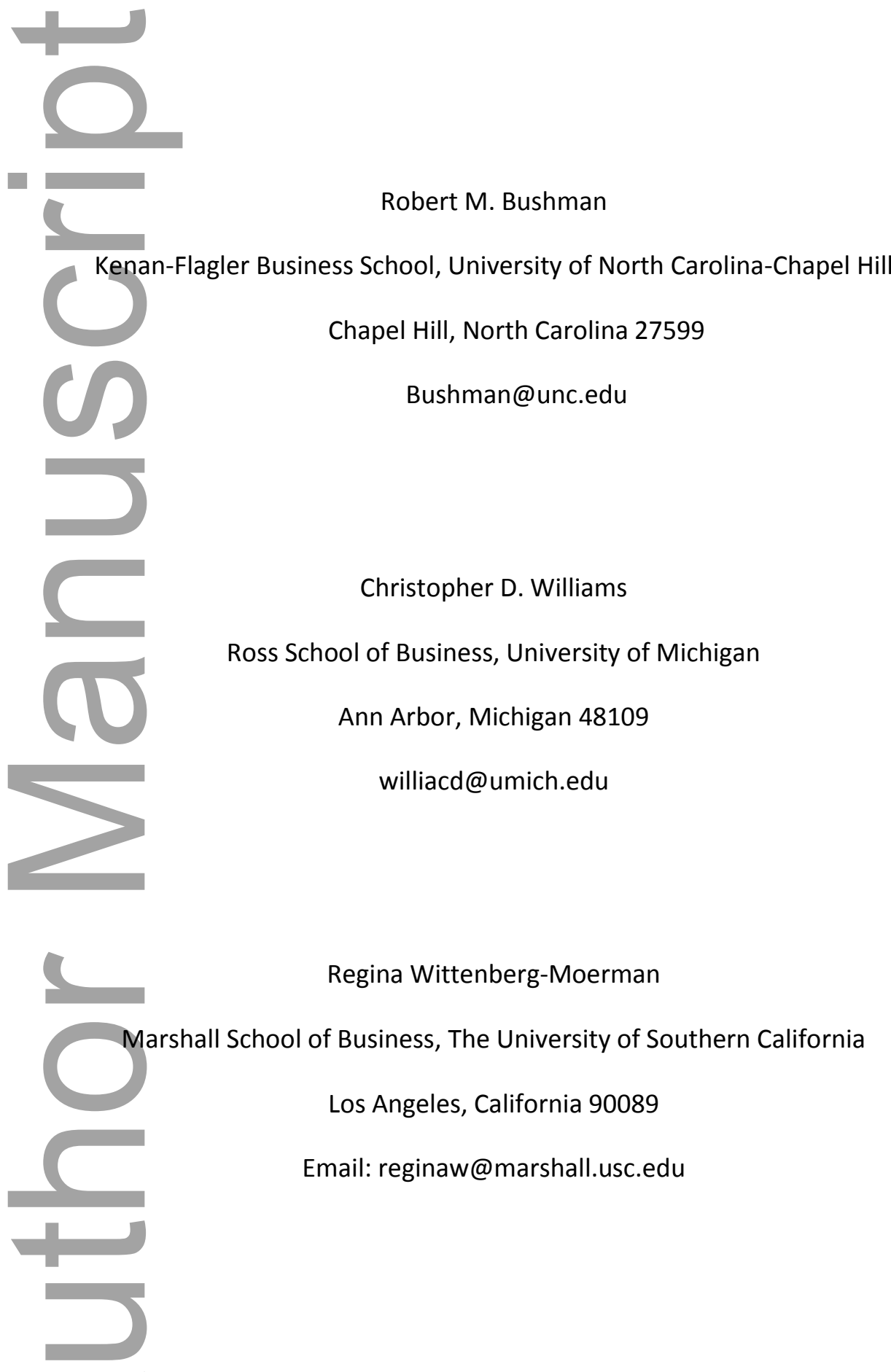

This is the author manuscript accepted for publication and has undergone full peer review but has not been through the copyediting, typesetting, pagination and proofreading process, which may lead to differences between this version and the Version of Record. Please cite this article as doi: 10.1111/1475-679X.12131.

This article is protected by copyright. All rights reserved. 


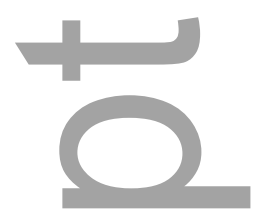

흔

c

* Accepted by Douglas Skinner. We appreciate the helpful comments of three anonymous reviewers, Robert Bloomfield, Doug Diamond, Yiwei Dow, Matthew Gentzkow, Wayne Guay (discussant), Christian Leuz, Amir Sufi, and participants at the George Washington University Cherry Blossom Accounting Conference, the Yale Fall 2013 conference, the Utah Winter Accounting Conference and seminar participants at Carnegie Mellon University, Columbia University, Cornell University, LBS, Pennsylvania State University, the University of Graz, the University of lowa, the University of Washington at Seattle and the Vienna Graduate School of Finance. We are very grateful to Vincent Pham for excellent research assistance. We thank the Thomson Reuters Loan Pricing Corporation for providing loan data. We thank RavenPack for providing media data and Malcolm Bain for many helpful discussions. We are grateful to Bryan Kelly for sharing data on analyst coverage reductions. We gratefully acknowledge the financial support of the Kenan-Flagler Business School, the University of North Carolina at Chapel Hill, the Ross School of Business, University of Michigan, the University of Chicago Booth School of Business and the University of Southern California, Marshall School of Business. An Online Appendix to this paper can be downloaded at http://research.chicagobooth.edu/arc/iournal-of-accounting-research/online-supplements

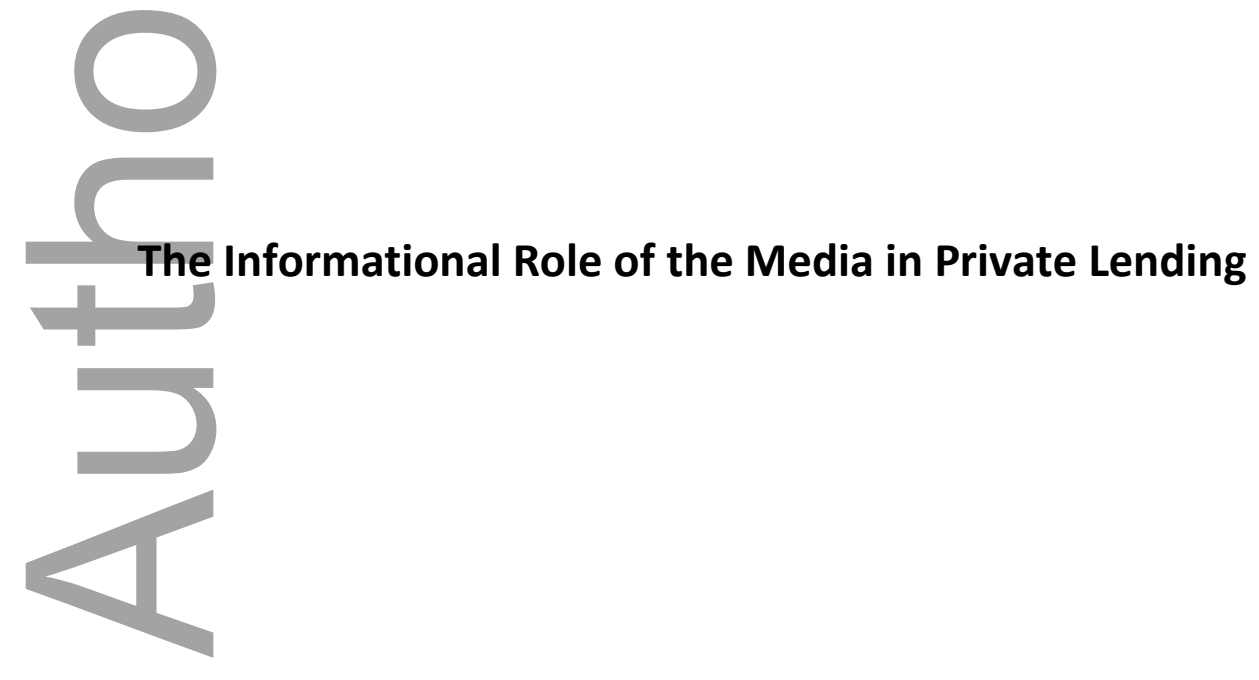

This article is protected by copyright. All rights reserved. 


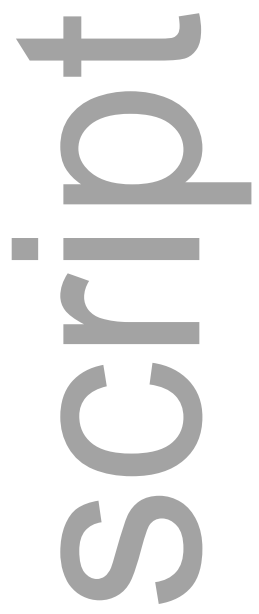

Abstract

We investigate whether a borrower's media coverage influences the syndicated loan origination and participation decisions of informationally disadvantaged lenders, loan syndicate structures and interest spreads. In syndicated loan deals, information asymmetries can exist between lenders that have a relationship with a borrower and less informed, non-relationship lenders competing to serve as lead arranger on a syndicated loan, and also between lead arrangers and less informed syndicate participants. Theory suggests that the aggressiveness with which less informed lenders compete for a loan deal increases in the sentiment of public information signals about a borrower. We extend this theory to syndicated loans and hypothesize that the likelihood of less informed lenders serving as the lead arranger or joining a loan syndicate is increasing in the sentiment of media-initiated, borrower-specific articles published prior to loan origination. We find that as media sentiment increases (1) outside, non-relationship lenders have a higher probability of originating loans; (2) syndicate participants are less likely to have a previous relationship with the borrower or lead bank; (3) lead banks retain a lower percentage of loans and (4) loan spreads decrease.
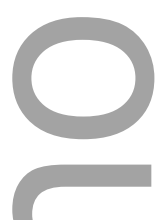

Keywords: media, relationship lending, syndicate structure, lead arranger, sentiment

JEL Classification: G12, G21, M40, M41

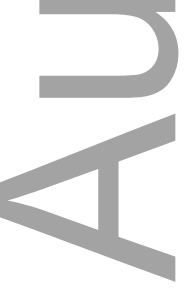

This article is protected by copyright. All rights reserved. 


\section{Introduction}

The business press is an important source of public information about a firm. There is substantial evidence that the business press provides information about firm fundamentals to equity market participants incremental to that provided by other information intermediaries and by accounting data (e.g., Tetlock et al., 2008), and that it reduces information asymmetries between equity investors (e.g., Bushee et al., 2010). However, there is little research examining the role played by the media in private lending markets. In this paper, we investigate the extent to which media coverage of borrowers influences the loan origination and participation decisions of informationally disadvantaged lenders, loan syndicate structures and interest rate spreads.

A defining feature of equity markets is that investors do not generally have privileged access to firms' confidential information, as securities law prohibits unequal access to such information. This creates scope for the media to serve as an information intermediary for equity investors seeking information from sources external to the firm. ${ }^{1}$ In contrast, private debt markets are not subject to securities laws, allowing lenders significant access to borrowers' private information as an integral part of the lending process. Syndicated loans involve multiple lenders where the degree of access to borrowers' inside information can differ substantially across lenders. Such differential access to information creates information asymmetries between lenders at two levels.

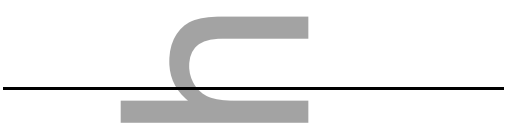

\footnotetext{
${ }^{1}$ Bushee et al. (2010) define an information intermediary as an agent that provides information that is new
} and useful to other parties because it has either not been publicly released or widely disseminated.

This is the author manuscript accepted for publication and has undergone full peer review but has not been through the copyediting, typesetting, pagination and proofreading process, which may lead to differences between this version and the Version of Record. Please cite this article as doi: 10.1111/1475-679X.12131.

This article is protected by copyright. All rights reserved. 
First, syndicated lending involves information asymmetry between inside lenders with a prior relationship with a borrower and outside, non-relationship lenders competing for a mandate to serve as the lead arranger on a borrower's loan. ${ }^{2}$ Non-relationship lenders are typically at an information disadvantage relative to relationship lenders. Through sustained engagement, relationship lead banks gain extensive inside knowledge of a borrower's operations and develop private channels of communication with its managers. Borrowers are also inclined to reveal sensitive private information to relationship lenders (e.g., Greenbaum and Thakor, 1995, Boot, 2000, and Bharath et al., 2009). ${ }^{3}$ Second, information asymmetries exist between lead banks and other syndicate participants (we use the terms lead arranger and lead bank interchangeably). Although participants can receive some private information from the lead bank or borrower, they are generally at an information disadvantage relative to the lead bank because they tend to maintain an arm's length relationship with the borrower, while the lead bank has the primary due diligence and monitoring responsibilities (e.g., Lee and Mullineaux, 2004, Sufi, 2007, and Ivashina, 2009).

Outside lenders, analogous to equity investors, have incentives to seek credit-relevant information about a borrower to mitigate their information disadvantage relative to more informed inside lenders. ${ }^{4}$ While media is unlikely to fully remove an inside lender's private information advantage, it can reduce relative information asymmetries across lenders and influence loan

\footnotetext{
${ }^{2}$ A lead arranger establishes a relationship with the borrower and has primary responsibility for information collection, ex-ante due diligence, distributing shares of the loan to syndicate participants and ex-post monitoring, among other duties. The lead arranger receives a fee for arranging and managing the syndicated loan. We discuss institutional aspects of syndicated lending in more detail in section 2.1.

${ }^{3}$ The idea that inside banks have an information advantage is well established in the literature (e.g., Kane and Malkiel, 1965, Fama, 1985, Greenbaum, Kanatas, and Venezia, 1989, Sharpe, 1990, Rajan, 1992, Petersen and Rajan, 1994, 1995, and Dell'Ariccia and Marquez, 2004).

${ }^{4}$ For parsimony, we often refer to lead arrangers with a relationship to a borrower and participant banks with a relationship to the lead arranger or a borrower as inside lenders, and other lenders as outside lenders. The premise is that inside lenders are better informed than are outside lenders.
} 
syndicate formation and pricing by transmitting credit relevant information to less informed lenders that is incremental to information received from other sources. We investigate the informational role of the media in syndicated lending by employing a quantitative measure of media sentiment in business press articles about a borrower. Using data from RavenPack News Analytics, we construct a measure that reflects the average sentiment across all full-size borrower-specific articles published over the six-month period preceding loan origination (Media Sentiment). RavenPack's sentiment score reflects assessments of the tone of the news in a given article (i.e., positive or negative news) as well as the strength of the news the article contains.

We first investigate if the media influences competition between inside and outside lenders for the mandate to serve as the lead arranger on a borrower's loan. This analysis builds on the model from Rajan (1992) in which an informed (inside) bank in a current lending relationship with a risky borrower competes with less informed (outside) banks to supply new financing to a borrower. Inside banks exploit their information advantage by opportunistically bidding only for good loans while avoiding bad ones. Because inside banks avoid bad loans, outside lenders are exposed to adverse selection as they face a significant risk of loss if they bid. Outside lenders respond by moderating how aggressively they compete, becoming more reluctant to participate as their assessed probability that a loan is bad increases. Rajan (1992) further considers how public information signals about a borrower shape competitive dynamics, showing that outside lenders' willingness to compete increases in the sentiment of the signal. A more favorable signal increases outside lenders' assessment of loan quality, reducing their risk of getting stuck with a bad loan and increasing the aggressiveness with which they compete against an inside lender. In contrast, a less favorable signal decreases outside lenders' willingness to compete due to heightened adverse selection concerns driven by lower assessed loan quality. The more (less) aggressively outsiders bid, the higher (lower) the probability is of their winning the loan deal. 
We extrapolate this economic reasoning to syndicated loans where inside, relationship lenders and outside, non-relationship lenders compete to be selected by a borrower as the lead arranger of the syndication. We empirically investigate whether media sentiment is associated with the probability that the lead arranger of a loan is an outside lender with no established relationship with a borrower. We hypothesize that the aggressiveness with which outside lenders compete to arrange a loan is increasing in media sentiment, thus raising their probability of winning the loan. We find that the probability of a non-relationship lender serving as a lead arranger is higher when media sentiment is more positive. A one standard deviation increase in media sentiment increases the probability that a loan is syndicated by a non-relationship lead arranger by $6.2 \%$.

We next consider whether the media influences the willingness of lenders to participate in a loan syndicate. We classify as more informed, inside participants those lenders who have a previous relationship with either the borrower or the loan's lead arranger (e.g., Sufi, 2007, and Ivashina, 2009), and as less informed outside participants those without a relationship. We hypothesize that the willingness of less informed lenders to participate in a loan syndicate is increasing in media sentiment. Because a lead arranger has an information advantage relative to syndicate participants and its monitoring effort after a loan closes is unobservable, participants face both adverse selection and moral hazard problems (e.g., Sufi, 2007, Ivashina, 2009, and Mora, 2015). While it is difficult to empirically distinguish adverse selection and moral hazard, we argue that the media can influence lenders' participation through either channel.

To motivate an adverse selection explanation, we extend the economic reasoning from Rajan (1992) to loan syndicates where loan participants compete to become syndicate members. In forming a syndicate, a lead bank sends out invitations to a large set of potential lenders who choose whether or not to bid on joining the syndicate. The number of invitations generally exceeds the number of lenders who ultimately participate (Champagne and Kryzanowski, 2007). As noted by 
Ivashina and Sun (2011), the syndication process can be viewed as an auction where loan participants submit sealed bids to the lead arranger. The same winner's curse issue developed in Rajan (1992) plausibly operates here to the extent that inside participants pursue good loans, leaving bad loans to less informed bidders. Analogous to Rajan (1992), the media can influence the severity of the winner's curse problem, where more positive media signals increase the willingness of nonrelationship (less informed) lenders to bid for loan participation.

Under moral hazard, syndicate participants are concerned about ex-post monitoring efforts of the lead arranger, where monitoring becomes more crucial for troubled borrowers (Sufi, 2007). If the media reveals negative news, outside participants plausibly downgrade their assessment of loan quality, which increases their concern about the lead arranger shirking. Thus, outside participants are less likely to join a syndicate than are relationship participants with superior information about the lead arranger and/or the borrower. Similar to the adverse selection case, outside lenders can either not submit bids or submit bids that are rejected by the lead arranger in favor of superior bids by relationship participants. Based on these arguments, we predict that the probability of nonrelationship syndicate participants joining the syndicate increases in media sentiment. We find evidence consistent with this prediction: a one standard deviation increase in Media Sentiment increases the probability that a participant without a prior relationship with the borrower (lead arranger) joins the syndicate by $7.1 \%(9.3 \%)$.

Next, we examine the proportion of a loan retained by the lead bank. Due to adverse selection and moral hazard concerns, syndicate participants require lead arrangers to put skin in the game by holding a proportion of the loan that is increasing in the severity of the agency problem (e.g., Leland and Pyle, 1977, Holmstrom and Tirole, 1997, and Sufi, 2007). Because, as argued above, more positive public signals are expected to decrease both adverse selection and moral hazard risks faced by less informed syndicate participants, we 
hypothesize that the loan share retained by the lead arranger is decreasing in media sentiment. We show that a one standard deviation increase in media sentiment decreases this proportion by $5.3 \%$.

Finally, we investigate whether more positive media sentiment is associated with lower interest rate spreads. We hypothesize that if, as argued earlier, loan attractiveness to nonrelationship lead arrangers and syndicate participants increases when media sentiment is more positive, the expanded set of potential lenders willing to fund the loan will increase the supply of credit available to the borrower and put downward pressure on interest spreads. We find that interest rate spreads are decreasing in media sentiment: a one standard deviation increase in Media Sentiment translates into a 6.9 basis point decrease in the spread.

Our previous analyses presume that the media provides new information to less informed lenders by publicly revealing either private information known to inside, but not outside, lenders, or information that is not previously known to either inside or outside lenders. To bolster this claim, we show that our findings with respect to lead arranger choice, syndicate participation, lead arranger share, and interest spreads are robust to controlling for alternative public information sources, including equity analysts, credit rating agencies, and firm-initiated press releases. Further, we split our sample into partitions based on the extent of firms' analyst coverage. Prior research shows that analysts provide useful information to lenders (e.g., Guntay and Hackbarth, 2010, and Mansi et al., 2011). This suggests that when analyst information is scarce, lenders face more uncertainty about a aris borrower's prospects and rely more on alternative information sources. We predict that if the media is informative to outside lenders, then the effect of media sentiment on private lending practices will be stronger when analyst coverage is less intensive. Consistently, we find that syndicate structure and loan spreads are more sensitive to media sentiment when analyst coverage is lower. We further find some evidence that the effect of media sentiment is stronger for borrowers that experience an 
exogenous reduction in analyst coverage preceding loan issuance.

Although our findings are consistent with the media providing incremental information to outside lenders, the media can also influence private lending deals through alternative channels. We explore one such channel by examining the possibility that the media influences consumers' perceptions of a borrower, changing their future purchasing decisions and consequently a borrower's future cash flows. For example, news that a consumer-product firm acted irresponsibly towards the environment may cause some consumers to abandon the firm's products. It is plausible that lenders would incorporate the expected impact of changes in consumer behavior on a borrower's future sales and cash flows into loan pricing. We thus hypothesis that the media, operating through a consumer perception channel, impacts the interest spreads of consumerproduct-oriented borrowers more intensively than it does the spreads of other borrowers. We find strong supporting evidence. This evidence suggests that the media can affect loan pricing via at least two channels - by informing outside lenders with limited access to private information and by changing consumers' perception of the borrower, which is in turn priced by lenders.

While our analyses provide robust evidence consistent with the media being a direct source of information to lenders, we cannot fully rule out the possibility that media sentiment proxies for information from other sources. However, whether the media is a direct source of information or simply mimics information from other sources, our results contribute to the literature by providing substantive evidence on the role of information signal sentiment in shaping loan deals. The evidence that lenders' decisions are influenced by media sentiment is consistent with the theory of Rajan (1992) and differentiates our analysis from prior studies that focus primarily on the availability of public information about a borrower without considering the role of its sentiment (e.g., Sufi, 2007, Ball et al., 2008, Ivashina, 2009 and Schenone, 2010). We extend the literature by demonstrating that critical aspects of syndicate lending, such as lead arranger choice, syndicate participation 
decisions, the loan share retained by the lead arranger and loan pricing are significantly associated with the sentiment of business press articles, controlling for alternative information sources about the borrower. We also provide novel evidence consistent with media sentiment impacting loan pricing via its influence on consumer perceptions and behavior.

Section 2 presents prior research that motivates our analyses and the hypotheses development. Section 3 describes the sample and data. Section 4 reports our main results and section 5 concludes the paper.

\section{Motivation and Related Literature}

\subsection{Information asymmetry between lenders competing to serve as a lead arranger}

Private debt contracts rely on the flow of confidential information between lenders and borrowers (e.g., Diamond, 1984, and Fama 1985). Confidential information includes hard information, such as timely financial disclosures, covenant compliance information, amendment and waiver requests, financial projections, and plans for acquisitions or dispositions (Standard and Poor's, 2011), as well as softer information, such as observations about a management team's abilities, and honesty (Petersen, 2004). Lenders with access to borrowers' confidential information are surely less reliant on public information than are equity investors. However, not all lenders have equivalent access to a borrower's private information, and information asymmetries across lenders create a demand from informationally disadvantaged lenders for public information.

A syndicated loan is a loan issued to a firm jointly by more than one financial institution. Members of a syndicate can be classified as either lead arrangers or participant lenders. The lead arranger initiates a loan, negotiates with a borrower, and then syndicates shares of the loan to participant lenders. The lead arranger's compensation consists of an upfront fee not shared with the rest of the syndicate and interest spread (Ivashina, 2009). This upfront fee increases with the 
complexity and riskiness of the loan (Standard and Poors, 2011). Lead arrangers also get private benefits from building a relationship with the borrower and gaining access to its future business (Yasuda, 2005, Drucker and Puri, 2005, and Mora, 2015). Before any loan participants are invited to join a syndicate, the borrower first selects the lead arranger from the set of competing lenders. Information asymmetry can affect the competition among lenders competing for a mandate to serve as the lead arranger on a loan. Here we must distinguish inside lenders with a prior relationship with a borrower and outside, non-relationship lenders.

Relationship lenders interact repeatedly with borrowers over an extended time period, and in the process gain extensive inside knowledge of the borrowers' operations and develop private channels of communication with managers. Due to this information advantage, relationships are an important source of an incumbent bank's comparative advantage over new lenders without a relationship (Boot, 2000). Thus, when lenders compete to serve as lead arranger, outside, nonrelationship lenders face adverse selection risk due to their pre-bidding information disadvantage. This adverse selection issue is the focus of Rajan (1992).

Rajan models competitive dynamics in private lending markets in a setting where a relationship bank competes for a borrower's loan with less informed (outside) banks. The premise is that the inside bank acquires private information through its privileged access to the borrower, while an outside bank lacks access. The model assumes that the inside bank knows for sure whether the firm will succeed or fail, while an outside bank has an assessed probability of success. ${ }^{5}$ Under these conditions, an outside bank is at a disadvantage in bidding against the inside lender. The outside bank understands that if it adopts an aggressive strategy of always bidding, the inside bank will exploit this predictability and always win good loans by offering the borrower slightly better terms

\footnotetext{
${ }^{5}$ Hauswald and Marquez (2006) demonstrate similar economic consequences of relationship lending in a model where inside banks are imperfectly, but better, informed than are outside banks.
} 
than does the outsider in the good state (when the firm will succeed) and leaving outside lenders with bad loans by not bidding in the bad state (when the firm will fail). This exposes the outsider to a winner's curse problem in which it only finances bad projects.

To deal with this problem, an outside lender plays a mixed strategy in which it randomizes bidding and not bidding. This implies that with some probability, the outside lender will not participate in the bidding process. Rajan (1992) shows that outsiders bid less frequently as their assessed probability that a loan is bad increases. Taking as given the outsider's mixed strategy, the insider's equilibrium strategy is to bid for good loans, but not for bad. For good loans, the insider offers a higher interest rate than outsiders do, knowing that when the outsider does not bid, the insider will win the loan and earn high profits, but lose the loan and earn zero profits if the outsider bids. In an important extension, Rajan (1992) shows that public disclosure influences outside lenders' probability of bidding by changing their assessments of loan quality. While a more positive signal increases outside lenders' assessments of loan quality, a more negative signal increases the adverse selection problem outside lenders face.

This leads to the result that the probability of an outsider bidding for a loan is higher for signals with higher sentiment. ${ }^{6}$ Further, the greater the probability of outsiders' bidding, the higher their probability is of winning the loan. Building on this intuition, we hypothesize that the probability of an outside, non-relationship lender serving as the lead arranger of a syndicated loan is increasing in media sentiment. Following Schenone (2010), we classify a loan as syndicated by a relationship lead arranger if the lender has syndicated a majority of the borrower's prior loan deals by volume

\footnotetext{
${ }^{6}$ While Rajan's (1992) model is analyzed in terms of only a good and bad signal, it is straightforward to generalize this result to a setting with more than two signals. What is required is that the Monotone Likelihood Ratio Property holds such that higher signals indicate a higher likelihood that the loan is good (Rajan's two signal model implicitly assumes MLRP). In this case, higher signals result in a greater probability of bidding. In the language of our paper, the probability of an outsider bidding for a loan monotonically increases in the sentiment of the information signal.
} 
over the five year period preceding the loan issuance date, and syndicated by a non-relationship lender otherwise. We construct a media sentiment variable using the RavenPack database to proxy for the sentiment of public information signals in Rajan (1992).

While Rajan (1992) describes well competition among differentially informed lenders to win a loan deal, the model does not directly consider information asymmetry issues associated with loan syndicate formation. We turn to this issue next.

\subsection{Information asymmetry within loan syndicates}

We examine whether the media influences the willingness of lenders to participate as members in a loan syndicate. Participant lenders generally do not directly communicate with the borrower and maintain an arm's length relationship through the lead arranger. The lead arranger establishes and maintains a relationship with the borrower and acts as an agent for the syndicate by collecting and processing information about the borrower. Prior to syndication, the lead bank conducts due diligence and presents an assessment of the borrower's quality to potential participants. Thus, participants face adverse selection risk because the lead bank can have an incentive to syndicate low quality loans (Sufi, 2007, and Ivashina, 2009). Lead banks can, for example, originate and then syndicate low quality loans to obtain upfront fees and capture private benefits, such as future cross-selling opportunities with the borrower (Mora, 2015). After syndication, the lead bank is charged with monitoring the borrower. This introduces a moral hazard risk as lead banks only retain part of the loan, which reduces incentives to monitor.

Most research on syndicate lending does not distinguish between the moral hazard and adverse selection risks (e.g., Ball et al., 2008, Ivashina, 2009, Dennis and Mullineaux, 2000, Jones et al., 2005). Empirically separating these two risks is challenging, as the consequences of moral hazard and adverse selection are generally observationally equivalent (Cohen and Siegelman, 2009). Although we do not attempt to distinguish between the two, we expect the media to influence 
lenders' participation through either an adverse selection or moral hazard channel.

The syndication process seeks to match borrowers with the set of lenders that value the loan most highly. To form a syndicate, a lead bank sends out invitations to a large set of potential lenders who choose whether to submit bids to join the syndicate. Invitations to bid generally outnumber acceptances, implying that many invitees choose not to participate (Champagne and Kryzanowski, 2007). ${ }^{7}$ Lenders that accept the invitation submit sealed bids directly to the lead bank. After bids are in, a minimum clearing spread is determined and investors who bid that spread or below are awarded a share of the loan on a pro-rata basis (Ivashina and Sun, 2011).

We extend the adverse selection dynamics reasoning from Rajan (1992) to competition among differentially informed lenders to become syndicate members. We posit that participants with a prior relationship with either the borrower or the lead arranger face less severe information risks than participants without a relationship. Thus, the winner's curse issue developed in Rajan (1992) is likely to play a role in lenders' syndicate participation decisions to the extent that inside participants pursue good loans, leaving bad loans for less informed bidders. In line with Rajan (1992), the media can influence the severity of the winner's curse problem, where more positive media signals increase the willingness of nonrelationship lenders to bid for loan participation. Note that outside lenders that do not join the syndicate can either not submit bids or submit bids that are rejected by the lead arranger in favor of superior bids by relationship participants.

With respect to moral hazard, because the severity of potential losses due to a lack of

${ }^{7}$ Sample loans have on average 9.6 syndicate participants. Champagne and Kryzanowski (2007) note that the number of invitations sent to potential syndicate participants is generally 3 times the number of participants that agree to join the syndicate, although this is likely to vary with the tightness of the supply of credit, the loan's purpose and the complexity of its structure, as well as future cross-selling possibilities, among other things. 
monitoring effort is likely to be higher for troubled borrowers (Sufi, 2007), negative media news can lower outside participants' assessments of loan quality and thus increase their concerns about lead arranger shirking. This can in turn increase the information disadvantage of non-relationship participants relative to relationship participants who possess enhanced channels of communication with the borrower or lead arranger. Thus, outside participants can be less willing to bid against relationship lenders or they can demand terms that are less favorable than those sought by relationship participants and therefore are rejected by the lead arranger. Based on these arguments, we hypothesize that the probability of non-relationship syndicate participants joining the syndicate increases in media sentiment also through the moral hazard channel.

We further examine the effect of the media on information asymmetry within syndicates by investigating whether media sentiment is associated with the proportion of the loan retained by the lead bank. Theory posits that a key mechanism for resolving information asymmetry issues and securing potential syndicate lenders willing to join the loan syndicate is to require lead banks to have skin in the game by holding a stake in the loan that increases in the severity of agency problems (e.g., Leland and Pyle, 1977, Diamond, 1984, and Holmström and Tirole, 1997). Empirical research provides evidence consistent with the theory. Sufi (2007) shows that lead banks hold a larger share of the loan when borrowers are more opaque, while Ball et al. (2008) show that the share retained by lead banks is decreasing in the debt contracting value of the borrower's accounting numbers. We extend and innovate on this literature by conjecturing that the share retained by the lead arranger depends not only on the fact that there is public disclosure, but also on the sentiment the disclosure conveys. Because, as argued earlier, a more positive public signal decreases adverse selection and moral hazard risk, we predict that the loan share retained by the lead arranger is decreasing in media sentiment.

\subsection{Media sentiment and loan pricing}


We next address whether media sentiment affects the interest rates. Rajan (1992) shows that more positive disclosure increases the aggressiveness of outside lenders in for a 11 bidding for a loan, which decreases the rents that inside lenders can extract from borrowers and thus results in lower interest rates. Recent empirical research exploits changes in a firm's information environment to identify how the information advantage of inside banks affects loan pricing. Hale and Santos (2009) examine how loan pricing changes following bond IPOs. They predict that when public information released during the IPO process reveals positive news about a borrower - that it is creditworthy - it increases outside banks' willingness to bid on its loans and consequently reduces inside lenders' information advantage. Consistently, they find that firms revealed as having investment grade credit ratings pay lower spreads on their loans after they undertake a bond IPO.

Hale and Santos (2009) rely on a significant information event to identify how public disclosure reduces inside banks' ability to extract rents from borrowers. We complement Hale and Santos (2009) by examining whether more favorable media sentiment results in lower spreads. In a syndicated loan setting, we expect more favorable media sentiment to increase both the aggressiveness with which outside lenders bid to arrange loans and to participate in loan syndicates, thus expanding the set of lenders willing to fund the loan. This expansion of potential lenders should increase the supply of credit available to the borrower. To the extent that interest spreads are negatively associated with the supply of credit (e.g., Ivashina and Sun, 2011), we predict that the wider range of syndicate participants and arrangers associated with more positive media sentiment results in lower loan pricing. 


\subsection{The role of the business press in capital markets}

The main premise of our paper is that the business press plays an important role in the private lending market by mitigating information asymmetries between differentially informed lenders. While there has been little research to date on this topic, a growing body of research demonstrates a substantive role played by the business press in the equity market. Although the information structures and contractual features of private lending differ from those of the equity markets, prior research supports the plausibility of our premise that the media can be informative to less informed outside lenders and influence their behavior.

Miller (2006) finds that the press serves as a watchdog for accounting fraud by rebroadcasting information from other information intermediaries and by undertaking original investigations that provide new information to the markets. Several papers find that media articles pressure firms to alter governance structures and strategic decisions, such as resource allocation, environmental policies and the structure of executive compensation (e,g., Dyck and Zingales, 2002, Bednar et al., 2012, Kuhnen and Niessen, 2012). ${ }^{8}$ For lenders without privileged access to a borrower, media articles that reveal fraud or pressure firms to alter governance and strategic choices can plausibly convey new information about the integrity of a borrower's executives, litigation risk, or changes in managerial incentives. These are important aspects of a lender's assessment of a borrower's future prospects and creditworthiness.

Further, there is evidence that the business press provides information about firm fundamentals to equity market participants over and above that provided by other information intermediaries and accounting data (e.g., Bushee et al., 2010, and Fang and Peress, 2009). Tetlock et al. (2008) finds that the fraction of negative words in firm-specific news stories forecasts low firm

\footnotetext{
${ }^{8}$ See Miller and Skinner (2015) for a more detailed discussion of the media literature.
} 
earnings and that equity prices quickly respond to the information in negative words. They suggest that linguistic media sentiment captures otherwise hard-to-quantify aspects of firms' fundamentals. ${ }^{9}$ It is thus plausible that the media can also impact private lending by providing information on hardto-quantify aspects of firms' fundamentals that underpin credit quality. Lenders' assessments of firms' credit risk can be affected by information about products, customers, competitors, industry growth potential, top executive teams, governance, regulation, legal issues, strategic plans, acquisitions, and labor markets, among many other topics (Green et al., 2012). The information revealed by the media can be new information not available to lenders from other sources, or it could be a signal that confirms, corroborates, or substantiates noisy information that lenders received from a different source. In the latter case, the media could, for example, confirm soft information the lender obtained elsewhere about the borrower, or allow the lender to filter noise from signals received from other sources. While our research design does not allow to distinguish the specific topics covered in the media articles underpinning media sentiment measure, extant research shows the power of a computational linguistics approach to quantify the language of a wide swath of firms' media coverage rather than focusing on specific categories of news. As noted by Tetlock et al. (2008), by quantifying language, researchers can examine the directional impact of a wide variety of events, rather than focusing on particular event types.

In addition to providing direct information to lenders about a borrower, the media can indirectly influence private lending deals by changing a borrower's circumstances through its impact on the behavior of a borrower's stakeholders. We explore one such channel by examining the possibility that the media influences consumers' perceptions of a borrower, changing their future

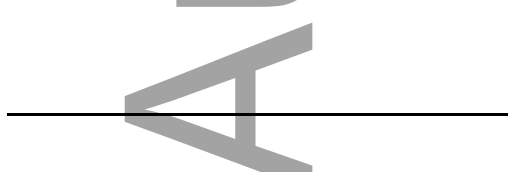

\footnotetext{
${ }^{9}$ See also Kothari et al. (2009), Boudoukh et al. (2012) and Rogers et al. (2016). In contrast, a number of recent papers suggest that media coverage might exacerbate information asymmetry and inefficient trading behavior (e.g., Frankel and Li, 2004, Green et al., 2012, and Soltes et al., 2014).
} 
purchasing decisions and consequently a borrower's future cash flows. ${ }^{10}$ The idea is that lenders would incorporate the expected consequences of these changes into the loan terms offered to the borrower.

\section{Sample, Data and Descriptive Statistics}

\subsection{Data sources and sample selection}

We employ the DealScan database provided by the Thomson Reuters Loan Pricing Corporation (TRLPC) to obtain loan-specific characteristics. Media sentiment scores are from RavenPack News Analytics, which covers all news disseminated via Dow Jones Newswires. RavenPack employs a variety of advanced textual analysis techniques to create news sentiment scores for business news stories. We obtain firm characteristics from Compustat. Firms' senior debt ratings, watchlist and outlook data (at the firm level) are retrieved from the S\&P historical database. For borrowers with no rating data in the S\&P database, we collect the S\&P, Moody's and Fitch ratings from the Internetbased version of TRLPC.

Table 1 summarizes the sample selection process. For the period from 2000 to 2012, DealScan reports 31,974 facilities issued to U.S. public firms in U.S. dollars. This time period reflects the availability of media data from RavenPack. Merging this sample with RavenPack leaves us with 24,308 facilities. Next, we exclude facilities with insufficient loan data, reducing the sample to 12,397 facilities. We also require borrowers to have sufficient Compustat data to estimate borrower characteristics and sufficient RavenPack data to estimate media sentiment prior to loan issuance. We estimate borrower characteristics in the quarter prior to the loan issuance and media sentiment

${ }^{10}$ Previous literature provides evidence that consumer behavior is sensitive to perceptions of a firm. For example, Lev et al. (2009) find that charitable contributions are significantly positively associated with future revenue, particularly for consumer-product-oriented firms. Similarly, Fisman et al. (2006) find that corporate philanthropy and profits are positively related, but only for firms in industries where a firm's image is important to consumers. 
over the 180 days prior to the loan issuance. ${ }^{11}$ We limit media data to full-size articles, excluding news flashes (news articles composed only of a headline and no body text), news articles composed of a headline and mostly tabular data, and firm-initiated press releases. We further restrict our sample to full-size articles with a relevance score of 75 and above. The relevance score is assigned by RavenPack to indicate when the firm is strongly related to the underlying news story. The scores range from 0 (low relevance) to 100 (high relevance). Our final sample contains 7,244 facilities related to 2,031 firms.

\subsection{Descriptive statistics}

Table 2 presents descriptive statistics for the main variables used in our tests (all variables are described in detail in Appendix A). Media Sentiment is estimated as the average news sentiment over the 180 days prior to a loan's origination date. We utilize RavenPack's Composite Sentiment Score (CSS), which represents the news sentiment of a given story by combining various textual analysis techniques (see Appendix A for a more detailed description of RavenPack's CSS measure). CSS scores range between 0 to 100, with a score above 50 indicating positive news; a score equal to 50 , neutral news; and a score below 50, negative news. We apply a linear transformation to the CSS score and define Media Sentiment $=($ CSS-50) $/ 50$, so that the Media Sentiment ranges from -1 to 1 , with zero being equivalent to neutral sentiment. The mean (median) value of Media Sentiment is $0.0046(0.0000)$

We examine five primary loan characteristics. Our first measure reflects the previous relationship of the lead arranger and the borrower. The mean value of Borr-Lead No-Relationship indicates that $63.8 \%$ of loans are issued by non-relationship lead arrangers. The next two measures

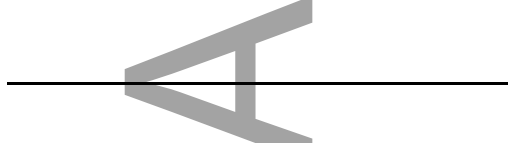

\footnotetext{
${ }^{11}$ We focus on the 180 days prior to the loan issuance to allow a sufficient time period prior to the start of the syndication process, which typically takes around 3 months. Our findings and inferences do not change if we estimate media coverage over 90 or 60 days prior to the loan issuance.
} 
are concerned with the previous relationships of the syndicate participants. Sample loan syndicates have on average 9.6 syndicate participants, indicating relatively large syndicates. The interquartile range of the number of participants is 11 , which suggests a high variation in syndicate structure for sample loans (untabulated). The mean value of Part-Borr No-Relationship indicates that $56.75 \%$ of syndicate participants have not participated in a borrower's syndicated loans in the five years preceding a loan's issuance. The mean value of Part-Lead No-Relationship indicates that $15.25 \%$ of syndicate participants have not participated in syndicates arranged by the loan's lead arranger in the five years preceding the loan's issuance. We also examine the proportion of a loan retained by the lead arranger. For loans with sufficient data, the mean (median) value of Lead Share is $21.05 \%$ (13.38\%). With respect to loan pricing, the average interest rate spread is 159.5 basis points (Spread is the logarithm of the interest spread).

With respect to sample firm characteristics, the average ratio of earnings before extraordinary items to total assets $(R O A)$ is $0.85 \%$. Sample firms have an average interest coverage ratio (Interest coverage) of 10.51, and average Leverage, measured as the ratio of total liabilities to total assets, of 0.25. Sample firms are also relatively large, with a mean value of total assets of $\$ 1,411 \mathrm{M}$ (Size is measured by the logarithm of the total assets). An average Altman's (1968) bankruptcy score (Zscore) is 2.24 (a higher score indicates a lower credit risk). The average market-to-book ratio is 3.01. $14.76 \%$ of the sample observations relate to the borrowers experiencing losses.

We report statistics for loan characteristics that serve as controls. Sample loans have an average size of $\$ 167.0 \mathrm{M}$ (Amount is the logarithm of loan amount) and a maturity (Maturity) of 47.9 months. The majority of the loans are revolvers (62.3 percent) and 10 percent are term loans $B$ and below, which are typically issued to non-bank institutional investors. 71.4 percent of the sample loans have performance pricing provisions (PP), 63.9 percent are secured (Collateral) and loans have on average 2.3 financial covenants (\#Covenants). 
Finally, we provide statistics for three alternative sources of information about borrowers. First, we estimate the sentiment of all borrower-initiated press releases over the 180 days prior to a loan's origination date. To isolate firm-initiated press releases, we impose a more stringent relevance criterion than the one applied to media articles and require a relevance score of 90 or greater. Press releases with a relevance score above 75 and below 90 often relate to cases where the firm is mentioned in the press releases of other firms. We apply a linear transformation to the CSS score and define Press Release Sentiment $=($ CSS-50)/50, so that Press Release Sentiment ranges from -1 to 1 , with zero being equivalent to neutral sentiment. Press release sentiment is typically positive, with a mean (median) value for Press Release Sentiment of 0.0243 (0.0264). Second, we report on whether the borrower is rated by a credit rating agency. $56 \%$ of sample loans are issued to rated borrowers. Third, because prior research suggests that equity analysts are informative to lenders (e.g., Guntay and Hackbarth, 2010, and Mansi et al., 2010), we measure whether a borrower has equity analyst coverage at loan origination. $87.5 \%$ of sample loans are issued to borrowers with analyst coverage.

To reflect additional information available about a borrower, we also estimate its abnormal stock returns over the same period during which sentiment is measured. Sample firms experience mean (median) abnormal returns of $5.6 \%(2.2 \%)$ over the 180 days prior to a loan's issuance (Return), with $42.75 \%$ of firms having a negative return over this period (Negative Return).

\section{Empirical Results}

We organize the discussion of our empirical findings into five subsections. Section 4.1 provides evidence on the association between media sentiment and the probability of a nonrelationship bank leading the loan deal. Section 4.2 examines relations between media sentiment and syndicate structure and section 4.3 considers those between media sentiment and loan pricing. In section 4.4, we provide evidence consistent with the media being a direct source of information to 
less informed, outside lenders. Finally, in section 4.5 we examine an additional channel through which the media may affect loan pricing.

\subsection{Media sentiment and the probability of a non-relationship bank leading the loan deal}

In this section, we examine whether media sentiment is positively associated with the probability of outside, non-relationship lenders serving as a lead arranger. We predict that a more positive media sentiment is associated with a higher probability that a lender without an established relationship with the borrower originates the loan. We estimate the following logistic model:

$$
\begin{aligned}
\text { Borr-Lead No-Relationship }=\alpha_{0} & +\beta_{1} \text { Media Sentiment }+\beta_{2} \text { Controls } \\
& +\beta_{3} \text { Alternative Info Sources },
\end{aligned}
$$

where Borr-Lead No-Relationship is an indicator variable equal to 1 if a loan is issued by a nonrelationship lender, and zero otherwise. ${ }^{12}$ Media Sentiment is our main variable of interest; we predict that $\beta_{1}>0$.

We control for a number of factors that prior research suggests are associated with the probability of a non-relationship lead arranger syndicating the loan (e.g., Gopalan et al., 2011, and Bolton et al., 2013), including whether a firm's previous loan is still outstanding when the current loan is issued (Outstanding), the time between the current and previous loan (Time Between) and the tightness of the credit supply in the economy (Tight Credit Supply). We proxy for credit supply tightness using changes in bank lending standards for mid-sized and large commercial loans, as reported in the Federal Reserve Board's quarterly Senior Loan Officer Opinion Survey on Bank Lending Practices (e.g., Bassett et al., 2012). The Tight Credit Supply variable takes a value of 1 if the change in lending standards in the quarter of a loan's origination is in the top quartile of the

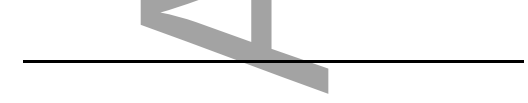

\footnotetext{
${ }^{12}$ To be able to measure this relationship variable, we restrict the estimation of model (1) to the sample of borrowers who issued at least one loan over the five-year period prior to a current loan's origination date.
} 
sample's distribution, and 0 otherwise.

We also control for a borrower's characteristics that reflect its creditworthiness, including profitability (ROA), interest coverage ratio (Interest Coverage), leverage (Leverage), size of total assets (Size), z-score (Z-score), the market-to-book ratio (MTB), and an indicator variable reflecting whether the borrower has experienced losses (Loss). In terms of loan-specific characteristics, we control for loan size (Amount), maturity (Maturity), whether the loan is a revolving line of credit (Revolver) and if the loan is a term loan B and below (Term Loan B).

Finally, we control for alternative information sources about the borrower, including its press release sentiment (Press Release Sentiment), whether it is rated (Rated) and whether it has analysts' coverage (Analyst Coverage). ${ }^{13}$ To reflect borrower-related news not captured by additional information sources and firm controls, we also include a borrower's abnormal stock returns (Return) and an indicator variable reflecting whether stock returns are negative (Negative Return), measured contemporaneously with Media Sentiment. Although stock returns impound all available information, there is still scope for Media Sentiment to play a direct role in informing lenders. The idea here is that the weights placed on the available information signals are tailored to the specific decision context at hand. While stock prices optimally aggregate all available information for valuation purposes, the weights on information signals that are optimal for valuing equity may not be optimal for assessing credit quality. Because a bank cannot generally look at changes in share price and extract the relevant signal from the many factors that move share price, outside banks can utilize relevant information from media stories and weight them appropriately in their credit decisions (Paul, 1992, Bushman and Indjejikian, 1993). ${ }^{14}$ Finally, we cluster the standard errors at the

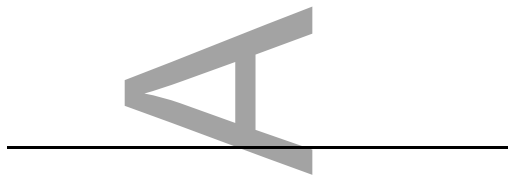

\footnotetext{
${ }^{13}$ In the Online Appendix, we show that our results are robust to including a more extensive set of measures of alternative information sources in the specification.
} 
firm and calendar quarter levels (this applies to all the remaining analyses). ${ }^{15}$

We present our findings Table 3. Consistent with the theory of Rajan (1992), we find that the coefficient on Media Sentiment is positive and significant, suggesting that the probability of a nonrelationship lead arranger syndicating the loan is increasing in media sentiment. A one standard deviation increase in media sentiment increases the probability that a loan is syndicated by a nonrelationship lead arranger by $6.2 \%$.

With respect to control variables, similar to Gopalan et al. (2011), we find that the probability of a non-relationship lender syndicating the loan decreases when the borrower's previous loan is still outstanding when the current loan is issued (Outstanding), but increases as the time span between the current and the previous loan increases (Time-Between). We do not find that the tightness of the credit supply significantly affects the probability of a non-relationship lead arranger originating the loan. The probability of a non-relationship lender syndicating the loan is also affected by a borrower's interest coverage, size, Z-score, and market-to-book ratio. When borrowers issue larger loans or loans with a longer maturity, we find that it is less likely for these loans to be arranged by non-relationship lenders. These results suggest that because non-relationship lenders have inferior access to a borrower's private information relative to relationship lenders, they are less willing to (2)

${ }^{14}$ Consider a simple example. Assume that equity investors' information set consists of two signals, $\mathrm{X}_{1}$ (e.g., media sentiment) and $X_{2}$ (another signal). This information is impounded into equilibrium price. Assume the equilibrium price applies equal weights to the signals giving: Price $=X_{1}+X_{2}$. Assume that for credit purposes, a lender would optimally weight the signals as: Credit quality $=\gamma_{1} X_{1}+\gamma_{2} X_{2}$. The lender cannot observe $X_{1}$ and $X_{2}$ separately, but instead observes $X_{1}$ and the stock price. How would lenders use these signals? Given that they want to optimally weight the signals for credit purposes, they would construct the following estimate of credit quality: Credit Quality $=\gamma_{1} X_{1}+\gamma_{2} *$ (Price $\left.-X_{1}\right)=\gamma_{1} X_{1}+\gamma_{2} X_{2}$. That is, even though the price fully impounds $X_{1}$ (e.g., media sentiment), lenders find it optimal to use $X_{1}$ in addition to price in order to achieve the desired weights on $X_{1}$ and $X_{2}$.

${ }^{15}$ Given Greene's (2004) criticism of the inclusion of fixed effects in non-linear models, we do not include year, industry and loan purpose fixed effects. The same applies to the probability of a non-relationship lender syndicate participation model. 
syndicate larger and longer term credit.

We find a negative coefficient on Press Release Sentiment. It is important to note here that press releases are an aspect of a firm's strategic disclosure decisions. For example, firms may issue positive press releases when they are trying to counter negative events or to run up stock prices around mergers (e.g., Davis and Tama-Sweet, 2012, and Ahern and Sosyura, 2014). Most important for our purposes is that our Media Sentiment result is robust to including press release sentiment, which rules out the possibility that media simply echoes firm press releases. We also find a negative coefficient on Analyst Coverage; this result is in line with Gopalan et al. (2011).

\subsection{The effect of media sentiment on syndicate participation and lead arranger share}

We next investigate the relation between media sentiment and syndicate participation. We predict that the likelihood of less informed lenders with no previous relationship with the borrower or the lead arranger participating in a syndicate is increasing in media sentiment. We follow Sufi (2007) and estimate the following logit model at the syndicate participant level:

Participation $=\alpha_{0}+\beta_{1}$ Media Sentiment $+\beta_{2}$ Controls $+\beta_{3}$ Alternative Info Sources,

where Participation is one of two participant relationship variables. Part-Borr No-Relationship is an indicator variable that is equal to one if the participant has not participated in a borrower's loans in the five years prior to a loan's issuance date, and zero otherwise. Part-Lead No Relationship is an indicator variable that is equal to one if the participant has not participated in a syndicate arranged by the loan's lead arranger in the five years preceding the loan's issuance, and zero otherwise. Media Sentiment is our main variable of interest, for which we predict $\beta_{1}>0$.

As in model (1), we control for borrower characteristics reflecting its creditworthiness. We also extend the set of loan-specific controls. We add controls for a borrower's previous relationship with the lead arranger (Borr-Lead No-Relationship) and for whether this is the first deal syndicated by the 
lead arranger (First Time Lead), as both can affect the attractiveness of the loan deal to participants.

We also control for whether the loan is secured (Collateral), the existence of performance pricing provisions $(P P)$ and the number of covenants (\#Covenants). ${ }^{16}$ Similar to model 1 , we control for alternative information sources about the borrower and its stock returns.

We present our findings in Table 4. In column 1, we report the estimation of model (1) with Part-Borr No-Relationship as the dependent variable. Consistent with our predictions, the coefficient on Media Sentiment is positive and significant, indicating that the probability of a participant with no relationship with the borrower joining the syndicate increases with media sentiment. This result is also economically significant: a one standard deviation increase in Media Sentiment increases this probability by $7.1 \%$.

With respect to controls, in line with lower information asymmetry between the lead arranger and participants when a borrower is more creditworthy, we find positive coefficients on ROA, Interest Coverage, and Z-Score and a negative coefficient on Leverage. We also find a positive coefficient on Borr-Lead No-Relationship, which suggests that the probability of non-relationship participants joining the syndicate increases when a new lead arranger with no previous relationship with the borrower arranges the loan. The coefficient on Press Release Sentiment is insignificant, suggesting that while media sentiment influences less informed participants, the content of firminitiated press releases does not incrementally affect their participation likelihood. When a firm is rated, the probability of a non-relationship participant joining the syndicate is significantly higher, consistent with their higher confidence in a loan's quality when creditworthiness is assessed by an independent third party (e.g., Sufi, 2007). Note that the coefficients on Return and Negative Return

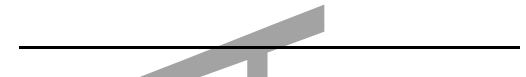

\footnotetext{
${ }^{16}$ We do not control for these three additional loan characteristics in model 1 , because they are typically determined during the negotiation process between a lead arranger and the borrower and therefore cannot affect the choice of the lead lender. In any case, in untabulated analyses, we find that our results are robust to the inclusion of these variables.
} 
are difficult to interpret. Stock returns consist of two components: changes in cash flow news and changes in discount rates (e.g., Vuolteenaho, 2002). Stock return controls therefore reflect both news about the firms's performance and the discount rate news associated with a firm's riskiness (our findings do not change when we control for return volatility).

In column 2, we report the results from the estimation of model (1) with Part-Lead NoRelationship as the dependent variable and find similar results. The coefficient on Media Sentiment is positive and significant, suggesting that the probability of a participant without a previous relationship with the lead arranger joining the syndicate increases with media sentiment. A one standard deviation increase in Media Sentiment increases this probability by $9.3 \%$. The coefficients on the control variables are generally consistent with those in column 1.

Our results so far indicate that more positive media sentiment extends the range of participants willing to join the syndicate to those without a relationship with the borrower or the lead arranger. Column 3 focuses on the loan share retained by the lead arranger (Lead Share). We predict that the share of a loan retained by the lead arranger is decreasing in media sentiment as participants require the lead to have less skin in the game.

We estimate model (2) as an OLS specification with Lead Share as the dependent variable. This specification also includes loan purpose ${ }^{17}$, industry and year fixed effects. In line with our expectations, we find a negative and significant coefficient on Media Sentiment. A one standard deviation increase in media sentiment decreases the loan proportion held by the lead arranger by 5.3\%. This evidence further supports a significant effect of media sentiment on syndicate structure and suggests that it operates via both channels - syndicate participants' willingness to join the

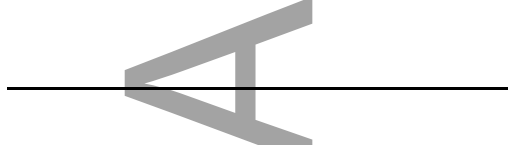

17 It is common in the literature to control for differences in the purpose of the loan (i.e., LBO, M\&A, restructuring, refinancing, general corporate purposes, etc.), as the riskiness of a loan and the level of information asymmetry across lenders can vary substantially by loan type. 
syndicate and the loan share the lead arranger is required to retain.

With respect to control variables, a lead arranger retains a smaller proportion of the loan when the borrower is larger and more profitable. Consistent with lower agency problems within the syndicate when a borrower is more transparent (e.g., Sufi, 2007), the lead arranger retains a smaller proportion of the loan when a borrower is rated and has analyst coverage. We also find that a nonrelationship lead arranger and a first time lead arranger hold a higher loan share, suggesting that participants require a lead arranger to have higher skin in the game in these cases.

\subsection{The effect of media sentiment on loan pricing}

Our analyses show that the decisions of less informed lenders to arrange and participate in syndicated loans are sensitive to media sentiment, where loan attractiveness is increasing in media sentiment. While it is important to show connections between media sentiment and lenders' decisions, our results thus far do not quantify the implications of media sentiment from the perspective of a borrower seeking financing. We examine this issue in this section.

As we show in our previous analyses, higher media sentiment not only increases a non-relationship lead arranger's aggressiveness in bidding for a loan, but also attracts less informed syndicate participants to join the syndicate. This expanded set of outside lenders is likely to increase the supply of financing available to fund the borrower's loan, exerting significant downward pressure on the interest rate spread.

To examine this hypothesis, we estimate the following OLS model: 
where Spread is the logarithm of the interest rate spread in basis points above LIBOR. We predict a negative coefficient on our main variable of interest - Media Sentiment. Variables reflecting controls and other information sources about the borrower are defined as previously. Further, the model includes loan purpose, industry and year fixed effects.

We present our findings in Table 5. Consistent with our predictions, we find that the interest spread is inversely associated with media sentiment, with more positive sentiment reducing the interest spread. In terms of economic significance, a one standard deviation increase in Media Sentiment translates into a 6.9 basis point decrease in spread. While this effect seems relatively modest, it is similar to the effect of a one standard deviation change in key credit risk measures, such as ROA (5.5 basis points) and Leverage (12.7 basis points).

With respect to controls, as expected, we report a negative relation between the spread and a borrower's profitability, size, Z-Score, and market-to-book ratio and a positive relation between the spread and leverage and an indicator variable reflecting losses. The coefficients on the loan-level controls are generally consistent with prior research. Larger loans and loans with pricing provisions are associated with lower spreads (Booth, 1992, and Asquith et al., 2005). Due to the endogenous determination of contractual terms, we observe a positive relation between the interest spread and both Collateral and \#Covenants (Berger and Udell, 1990, Bradley and Roberts, 2004, and Costello and Wittenberg-Moerman, 2011). ${ }^{18}$ While concurrently endogenizing all loan terms is beyond the scope of our paper, in untabulated analyses we estimate the interest rate model excluding loan

\footnotetext{
${ }^{18}$ Agency theory suggests that there is a trade-off between the restrictions imposed by the loan contract and the interest spread (Jensen and Meckling, 1979, Myers, 1977, and Smith and Warner, 1979). However, because more risky borrowers are likely to have higher spreads and lenders can simultaneously impose a higher number of covenants and/or require them to provide collateral, empirical tests typically reveal a positive relation between these variables.
} 
controls; our findings are unchanged. We find that revolvers (Term Loans B and below) are priced at lower (higher) rates, consistent with prior research (Harjoto et al., 2004, Zhang, 2008, Nandy and Shao, 2010, and Lim et al., 2014). We also show that more positive press release sentiment and analyst coverage are negatively associated with the spread.

The results presented in Tables 3-5 are consistent with the media providing incremental information to less informed, non-relationship lenders. To further support our claim that these lenders learn directly from the media, in an Online Appendix we provide additional analyses that address alternative information sources available for lenders in more detail. In particular, with respect to information provided by rating agencies, we account for the level of a borrower's credit rating, whether it is on a credit watchlist and its long-term credit outlook at a loan's issuance date as well as over the 180 days period prior to the issuance. We also account for equity analysts' earnings forecasts and recommendations at the time of a loan's issuance and the forecast and recommendation revisions over the 180 days prior to the issuance. We find that our main findings and inferences are robust to controlling for these additional information variables.

\subsection{Is the media a direct source of information to less informed, outside lenders?}

To provide further evidence that the media is a direct source of information to lenders, we conduct analyses conditional on the intensity of a borrower's analysts' coverage. We conjecture that if media sentiment is informative to less informed lenders, its effect on syndicate structure will be stronger when a borrower's coverage by other information intermediaries is less intensive. This prediction is motivated by prior evidence that analysts are an important information source to lenders (e.g., Guntay and Hackbarth, 2010, and Mansi et al., 2010). Therefore, outside lenders will rely more on alternative information sources, such as the media, when analyst following is relatively low. The idea is that investors' posterior expectations will respond more intensively to an information signal of a given precision, as prior uncertainty about a firm's prospects increases (e.g., 
Verrecchia, 2001). We classify borrowers as having highly intensive analyst coverage if the number of analysts covering the firm falls into the top quintile of the sample distribution, and as less intensive otherwise. We then estimate models (1), (2), and (3) for the two subsamples - borrowers with highly intensive and less intensive coverage. ${ }^{19}$ We report these tests in Table 6.

As evidenced from Panel A, for the lead arranger analyses, the coefficient on Media Sentiment is positive and significant for the less intensive analyst coverage partition, but it is not significant for the highly intensive coverage partition, although the difference in the coefficients between the two partitions is not significant. Economically, for the less intensive analyst coverage partition, a one standard deviation increase in Media Sentiment increases the probability that a lender without a prior relationship with the borrower arranges the loan by $7.6 \%$.

We find that for both the Part-Borr No-Relationship and Part-Lead No-Relationship specifications, the coefficient on Media Sentiment is negative and significant for the less intensive analyst coverage partition, but it is not significant for the highly intensive coverage partition (Table 6, Panels B and C). The difference in coefficients on Media Sentiment between these partitions is also statistically significant. For the less intensive analyst coverage subsample, a one standard deviation increase in Media Sentiment increases the probability that a syndicate participant without a prior relationship with the borrower (lead arranger) joins the syndicate by $12.1 \%(12.1 \%)$. The results are similar when we examine the lead bank's loan share aspect of the syndicate structure (Table 6, Panel D). The effect of media sentiment is significant for borrowers with less intensive analyst coverage, but not for those with highly intensive coverage. The difference in coefficients on Media Sentiment between the two partitions is significant at the $10 \%$ level. For borrowers with less intensive analyst coverage, a one standard deviation increase in Media Sentiment decreases the proportion held by

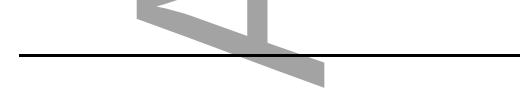

19 For all analyses, our results are robust when we define borrowers as having highly intensive analyst coverage if the number of analysts covering the firm falls into the top quartile of the sample distribution. 
the lead arranger by $4.6 \%$.

We also predict that the effect of media sentiment on the interest spread will be stronger for the less intensive analyst coverage partition. In Table 6, Panel E, we report that the coefficient on Media Sentiment is negative and significant for the less intensive coverage partition, but not significant for the highly intensive partition. The difference in coefficients on Media Sentiment between these partitions is statistically significant. For the less intensive analyst coverage subsample, a one standard deviation increase in Media Sentiment translates into a 7.3 basis points decrease in the interest spread.

The results presented in Table 6, Panels A-E are in line with the media providing more informative public signals to syndicate participants when information production by other information intermediaries is less intensive. However, firms with intensive analyst coverage can potentially differ from firms with less intensive coverage across a number of dimensions. We therefore examine how the effect of media sentiment differs across borrowers that have experienced a reduction in analysts' coverage prior to loan initiation and those that have not. A reduction in analyst coverage has been shown to be associated with an exogenous (unrelated to changes in firm fundamentals) decrease in public information production about the firm (e.g., Kelly and Ljungqvist, 2012, and Balakrishnan et al., 2013). We hypothesize that media signals will be more informative to non-relationship lead arrangers and syndicate participants following coverage reductions. We report these analyses in Table 7.

We identify that $4.3 \%$ of observations in the lead arranger analyses, $6.3 \%$ in the syndicate participant analyses, $4.2 \%$ in the lender share analyses, and $4.5 \%$ in the loan spread analysis relate to borrowers that have experienced a reduction in analyst coverage over the year preceding loan 
issuance. ${ }^{20}$ Despite the small size of the coverage reduction partition, we find a significantly higher coefficient on Media Sentiment for this partition in Borr-Lead No-Relationship, Part-Borr NoRelationship and Spread analyses (Panels A, B and E). For the Lead Share analyses (Panel D), the coefficient on Media Sentiment for the analyst coverage reduction partition is higher than the respective coefficient for the no coverage reduction partition, but the difference is not statistically significant, likely due to the extremely small sample size of the coverage reduction partition. ${ }^{21}$

Overall, the stronger effects of media sentiment on the likelihood of a nonrelationship lead arranger, syndicate structure, and loan pricing for the less intensive analyst coverage and reduction in analyst coverage partitions reinforce our inference that the media serves as a direct source of information to less informed, outside lenders.

\subsection{The sensitivity of interest spreads to media sentiment for consumer-product firms}

The results in Tables 3-7 suggest that the media influences loan pricing by providing incremental information to outside lenders, which increases the supply of credit by attracting non-relationship lead arrangers and syndicate participants. In this section, we explore an additional channel through which the media can affect interest spreads by examining the possibility that the media influences consumers' perceptions of a borrower, changing their future purchasing decisions and consequently a borrower's future cash flows.

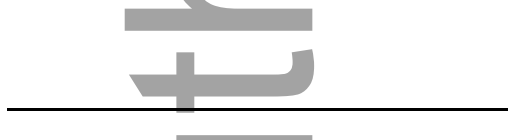

20 When we measure analyst coverage reduction over the 180 day period prior to loan issuance, the proportion of borrowers that have experienced a reduction in analyst coverage becomes even smaller, preventing us from conducting empirical analyses.

${ }^{21}$ For Part-Lead No-Relationship analysis (Panel C), we do not find that the coefficient on Media Sentiment is significantly higher for the analyst reduction partition. This could be due to a lack of power in this small sample setting, as prior research has shown that a previous relationship between a participant and lead arranger is relatively less important than a previous relationship between a participant and the borrower (Sufi, 2007). 
Specifically, we examine whether spreads are more sensitive to media sentiment for consumer-product-oriented firms. Consumers' decisions to purchase a firm's products are potentially influenced by positive or negative news about the firm, affecting its future sales and cash flows. Because lenders are likely to incorporate the behavior of a borrower's consumers into loan pricing, we predict that the effect of media sentiment on loan pricing is likely to be more pronounced for more consumer-product oriented firms.

Following Fisman et al. (2006), we identify whether a borrower is consumer product oriented by the relative importance of its advertising expenses. We classify borrowers as having high consumer-product intensity if the ratio of advertising expenses to sales revenue is above the sample median. We estimate the interest rate model for the consumer-product intensity partitions and report our findings in Table 8. Consistent with our predictions, we find that although the coefficient on Media Sentiment is negative and significant for both partitions, it is significantly larger for the high consumer-product intensity partition relative to the low intensity partition.

Overall, our interest spread analyses suggests that media sentiment affects loan pricing both by informing less informed outside lenders and by changing consumers' perception of a borrower, the implications of which are priced by lenders.

\section{Summary}

This paper examines whether media coverage influences the syndicated loan origination and participation decisions of informationally disadvantaged lenders, loan syndicate structures and interest spreads. We first investigate if the media influences competition between inside and outside lenders to serve as lead arranger on a borrower's loan. This analysis builds on Rajan (1992) who shows that the aggressiveness with which less informed lenders compete for a loan deal increases in the sentiment of public information signals about a borrower. We find that the probability of a non- 
relationship lender serving as a lead arranger is higher when media sentiment is more positive.

We also consider whether media sentiment influences the willingness of lenders to participate as members in a loan syndicate. Syndicate participants face both adverse selection and moral hazard problems (e.g., Sufi, 2007, Ivashina, 2009) and the media can influence lenders' participation through either channel. We find that the probability of non-relationship participants joining the syndicate increases in media sentiment. Consistent with more positive media sentiment reducing the agency problems faced by less informed participants, we also show that the loan share retained by the lead arranger (i.e., the lead's skin in the game) is decreasing in media sentiment. We finally show that more positive media sentiment is associated with a lower interest rate spread. We attribute this finding to the increased supply of credit available to the borrower due to more positive media sentiment attracting non-relationship lead arrangers and syndicate participants.

Further, we provide evidence consistent with the media being a direct source of information to lenders. First, we show that our results hold after controlling extensively for alternative public information sources, including analysts, rating agencies, and firm-initiated press releases. Second, we show that loan origination and participation decisions, as well as the loan share retained by the lead arranger and loan pricing, are more sensitive to media sentiment when a borrower's analyst coverage is lower and for borrowers that have experienced an exogenous reduction in analyst coverage preceding loan issuance. Finally, we provide evidence that loan spreads are more sensitive to media sentiment for consumer-product-oriented borrowers, consistent with lenders accounting for the implications of the news for consumers' perception of a borrower and the resultant impact on the borrower's future sales and cash flows.

By providing evidence that the media serves as an important information intermediary in the private debt market, we extend the growing body of research on the role played by the media in capital markets. Our findings also add to the extensive literature on syndicated lending, as we 
demonstrate that the media fundamentally alters the information structure and the nature of competition in the loan market. In particular, an important insight gleaned from our work is that not (

only the availability of public information about a borrower, but also its sentiment significantly influences the central characteristics of syndicated lending.

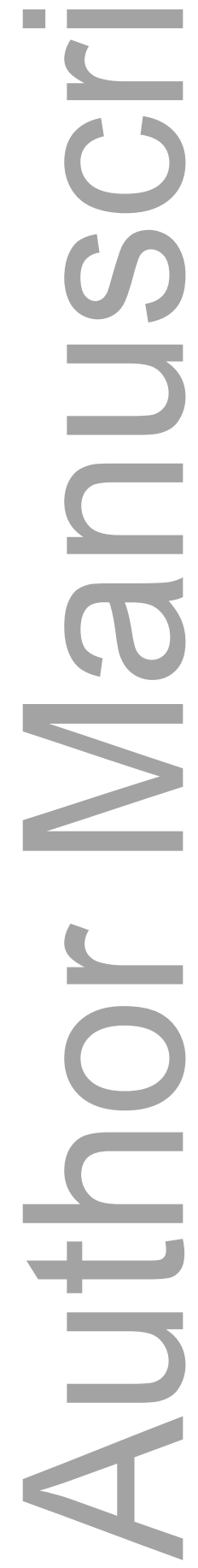




\section{References}

Ahern, K., and D. Sosyura, 2014, Who writes the news? Corporate press releases during merger negotiations, Journal of Finance, 69, 241-291.

Altman, E., 1968, Financial ratios, discriminant analysis and the prediction of corporate bankruptcy, The Journal of Finance, 23, 589-609.

Asquith, P., A. Beatty, and J. Weber, 2005, Performance pricing in bank debt contracts, Journal of Accounting and Economics, 40, 101-128.

Baker, M., and J. Wurgler, 2006, Investor sentiment and the cross-section of stock returns, The Journal of Finance, 61, 1645-1680.

Ball, R., R. Bushman, and F. Vasvari. 2008, The debt-contracting value of accounting information and loan syndicate structure, Journal of Accounting Research, 46, 247-287.

Bassett, W., M. Chosak, J. Driscoll, and E. Zakrajsek, 2012, Changes in bank lending standards and the macroeconomy, Finance and Economics Discussion Series Divisions of Research \& Statistics and Monetary Affairs Federal Reserve Board, Washington, D.C.

Benston, G., and L. Wall, 2005, How should banks account for loan losses? Economic Review, Fourth Quarter, 2005, Federal Reserve Bank of Atlanta.

Berger, A., and G. Udell, 1990, Collateral, loan quality and bank risk, Journal of Monetary Economics, 251, 21-42.

Bharath, S., S. Dahiya, A. Saunders, and A. Srinivasan, 2009, Lending relationships and loan contract terms, Review of Financial Studies, 24, 1141-1203.

Bolton, P., X. Freixas, L. Gambacorta, and P. Mistrulli, 2013, Relationship and transaction lending in a crisis, Working Paper.

Boot, A., 2000, Relationship banking: What do we know?, Journal of Financial Intermediation, 9, 725.

Boot, A., and A. Thakor, 1994, Moral hazard and secured lending in an infinitely repeated credit market game, International Economic Review, 35(4), 899-920.

Booth, J., 1992, Contract costs, bank loans, and the cross-monitoring hypothesis, Journal of Financial Economics, 31, 25-42.

Boudoukh, J., R. Feldman, S. Kogan, and M. Richardson, 2013, Which news moves stock prices? A textual analysis. NBER Working Paper No. w18725.

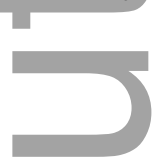

This is the author manuscript accepted for publication and has undergone full peer review but has not been through the copyediting, typesetting, pagination and proofreading process, which may lead to differences between this version and the Version of Record. Please cite this article as doi:

10.1111/1475-679X.12131.

This article is protected by copyright. All rights reserved. 
Bradley, M., and M. Roberts, 2004, The structure and pricing of corporate debt covenants, Working Paper.

Bushee, B., J. Core, W. Guay, and S. Hamm, 2010, The role of the business press as an information intermediary, Journal of Accounting Research, 48, 1-19.

Bushman, R., A. Smith, and R. Wittenberg-Moerman, 2010, Price discovery and dissemination of private information by loan syndicate participants, Journal of Accounting Research, 48, 921972.

Champagne, C., and L. Kryzanowski, 2007, Are current syndicated loan alliances related to past alliances?, Journal of Banking \& Finance 31(10), 3145-3161.

Cohen, A., and P. Siegelman, 2010, Testing for adverse selection in insurance markets, Journal of Risk and Insurance, 77(1), 39-84.

Core, J., W. Guay, and D. Larcker, 2008, The power of the pen and executive compensation, Journal of Financial Economics, 88, 1-25.

Costello, A., and R. Wittenberg Moerman, 2011, The impact of financial reporting quality on debt contracting: Evidence from internal control weakness reports, Journal of Accounting Research, 49, 97-136.

Davis, A. and I. Tama-Sweet, 2012, Managers' use of language across alternative disclosure outlets: Earnings press releases versus MD\&A, Contemporary Accounting Research, 29(3), 804-837.

Dell'Ariccia, G., and R. Marquez, 2004, Information and bank credit allocation, Journal of Financial Economics, 72, 185-214.

Dennis, S., and D. Mullineaux, 2000, Syndicated loans, Journal of Financial Intermediation, 9, 404426.

Diamond, $D_{2}, 1984$. Financial intermediation and delegated monitoring. Review of Economic Studies $51(3), 393-414$.

Dougal, C., J. Engelberg, D. Garcia, and C. Parsons, 2012, Journalists and the stock market, Review of Financial Studies, 25(4), 639-679.

Drucker, S., and M. Puri, 2009, On loan sales, loan contracting, and lending relationships, Review of Financial Studies, 22, 2635-2672.

Dyck, A. and L. Zingales, 2002, The corporate governance role of the media, The World Bank, Washington DC.

Engelberg, J., and C. Parsons, 2011, The causal impact of media in financial markets. Journal of Finance, 66, 67-97.

Fama, E., 1985, What's different about banks?, Journal of Monetary Economics, 15, 29-39.

Fang, L., and J. Peress, 2009, Media coverage and the cross-section of stock returns, The Journal of Finance, 64, 2023-2052.

Fisman, R., G. Heal, and V. Nair, 2006, A model of corporate philanthropy, Working Paper. 
Frankel, R., and X. Li, 2004, Characteristics of a firm's information environment and the information asymmetry between insiders and outsiders, Journal of Accounting and Economics, 37, 229259.

Gopalan, R., G. Udell, and V. Yerramilli, 2011, Why do firms form new banking relationships? Journal of Financial and Quantitative Analysis, 46, 1335-1365.

Green, J., J. Hand, and M. Penn, 2012, The bad news dissemination bias in the business press, Working Paper.

Greenbaum, S., G. Kanatas, and I. Venezia, 1989, Equilibrium loan pricing under the bank-client relationship, Journal of Banking and Finance, 13, 221-235.

Greenbaum, S., and A. Thakor, 1995, Contemporary financial intermediation (Dryden Press, Fort Worth, TX).

Greene, W., 2004, The behaviour of the maximum likelihood estimator of limited dependent variable models in the presence of fixed effects, Econometrics Journal, 7, 98-119.

Greene, W., 2010, Testing hypotheses about interaction terms in nonlinear models, Economics Letters, 107, 291-296.

Gregoriou, G., 2015, Handbook of high frequency trading, Academic Press, 1st edition, Elsevier, London, UK.

Guntay, L., and D. Hackbarth, 2010, Corporate bond credit spreads and forecast dispersion, Journal of Banking and Finance, 34(10), 2328-2345.

Hale, G., and J. Santos, 2009, Do banks price their informational monopoly? Journal of Financial Economics, 93, 185-206.

Harjoto, M., D. Mullineaux, and H. Yi, 2006, Loan pricing at investment versus commercial banks, Financial Management, 35, 49-70.

Hauswald, R., and R. Marquez, 2003, Information technology and financial services competition, Review of Financial Studies, 16, 921-48.

Hauswald, R., and R. Marquez, 2006, Competition and strategic information acquisition in credit markets, Review of Financial Studies 19, 967-1000.

Holmström, B., and J. Tirole, 1997. Financial intermediation, loanable funds, and the real sector. The Quarterly Journal of Economics, 112, 663-691.

Ivashina, V., 2009, The effects of syndicate structure on loan spreads, Journal of Financial Economics, 92, 300-319.

Ivashina, V., and Z. Sun, 2011, Institutional demand pressure and the cost of corporate loans, Journal of Financial Economics, 99(3), 500-522.

Jensen, M., and W. Meckling, 1976, Theory of the firm: Managerial behavior, agency costs, and capital structure, Journal of Financial Economics, 3, 305-360.

Joe, J., H. Louis and D. Robinson, 2009, Managers' and investors' responses to media exposure of board ineffectiveness, Journal of Financial and Quantitative Analysis, 44, 579-605.

Jones, J., W. Lang, and P. Nigro, 2005, Agent bank behavior in bank loan syndications, Journal of Financial Research, 28, 385-402. 
Kane, E., and B. Malkiel, 1965, Bank portfolio allocation, deposit variability, and the availability doctrine, Quarterly Journal of Economics, 79, 113-134.

Kelly, B., and A. Ljungqvist, 2012, Testing asymmetric-information asset pricing models, Review of Financial Studies, 25, 1366-1413.

Kothari, S. P., X. Li, and J. Short, 2009, The effect of disclosures by management, analysts, and business press on cost of capital, return volatility, and analyst forecasts: A study using sentiment analysis, The Accounting Review, 84, 1639-1670.

Kuhnen, C., and A. Niessen, 2012, Public opinion and executive compensation, Management Science, 58, 1249-1272.

Lee, S., and D. Mullineaux, 2004, Monitoring, financial distress, and the structure of commercial lending syndicates, Financial Management, 33, 107-130.

Leland, H. and D. Pyle, 1977, Informational asymmetries, financial structure, and financial intermediation, Journal of Finance, 32, 371-387.

Lev, B., C. Petrovits, and S. Radhakrishnan, 2009, Is doing good good for you? How corporate charitable contributions enhance revenue growth, Strategic Management Journal, 31, 182200.

Lim, J., B. Minton, and M. Weisbach, 2014, Syndicated loan spreads and the composition of the syndicate, Journal of Financial Economics, 111, 45-69.

Mansi, S., W. Maxwell, and D. Miller, 2011, Analyst forecast characteristics and the cost of debt, Review of Accounting Studies, 16, 116-142.

Miller, G., 2006, The press as a watchdog for accounting fraud, Journal of Accounting Research, 44, 1001-33.

Miller, G., and D. Skinner, 2015, The evolving disclosure landscape: How changes in technology, the media, and capital markets are affecting disclosure. Journal of Accounting Research, 53, 221239.

Mora, N., 2015, Lender exposure and effort in the syndicated loan market, Journal of Risk and Insurance, 82(1), 205-252,

Myers, S., 1977, Determinants of corporate borrowing, Journal of Financial Economics, 5, 147-176.

Nandy, D., and P. Shao, 2010, Institutional investment in syndicated loans, Working Paper.

Petersen, M., and Rajan, R., 1994, The benefits of lending relationships: Evidence from small business data, The Journal of Finance, 49, 3-37.

Petersen, M., and R. Rajan, 1995, The effects of credit market competition on lending relationships, Quarterly Journal of Economics, 110, 407-43.

Petersen, M. A., 2004. Information: Hard and soft. Working paper.

Rajan, R., 1992, Insiders and outsiders: The choice between informed and arm's-length debt, Journal of Finance, $47,1367-1400$.

Rogers, J., D. Skinner, and S. Zechman, 2016, The role of the media in disseminating insider trading news, Review of Accounting Studies, forthcoming. 
Roll, R., 1988, R², Journal of Finance, 43, 541-566.

Santos, J., and A. Winton, 2008, Bank loans, bonds, and information monopolies across the business cycle, The Journal of Finance, 63, 1315-1359.

Schenone, C., 2010, Lending relationships and information rents: Do banks exploit their information advantages?, Review of Financial Studies, 23, 1149-1199.

Sharpe, S., 1990, Asymmetric information, bank lending, and implicit contracts: A stylized model of customer relationships, Journal of Finance, 45, 1069-1087.

Smith, C., and J. Warner, 1979, On financial contracting: An analysis of bond covenants, Journal of FinancialEconomics, 7, 117-161.

Soltes, E., D. Solomon, and D. Sosyura, 2014, Winners in the spotlight: Media coverage of fund holdings as a driver of flows, Journal of Financial Economics, 113, 53-72.

Standard \&Poor's, 2011, A guide to the loan market, Standard \& Poor's, New York.

Sufi, A., 2007, Information asymmetry and financing arrangements: Evidence from syndicated loans, The Journal of Finance, 62, 629-668.

Tetlock, P., 2007, Giving sentiment to investor sentiment: The role of media in the stock market, The Journal of Finance, 62, 1139-1168.

Tetlock, P., M. Saar-Tsechansky, and S. Macskassy, 2008, More than words: Quantifying language to measure firms' fundamentals, Journal of Finance, 63, 1437-67.

Verrecchia, R., 2001, Essays on disclosure, Journal of Accounting and Economics 32, 97-180.

Vuolteenaho, T., 2002, What drives firm-level stock returns? The Journal of Finance, 57, 233-264.

Yasuda, A., 2005, Do bank relationships affect the firm's underwriter choice in the corporate-bond underwriting market?, Journal of Finance 60, 1259-92.

Zhang, J., 2008, The contracting benefits of accounting conservatism to lenders and borrowers, Journal of Accounting and Economics, 45, 27-54.

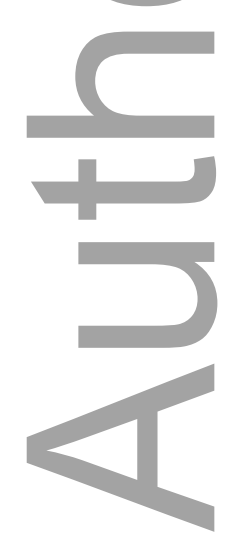




\section{Appendix A: Variable Definitions}

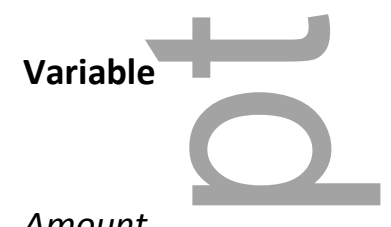

Amount

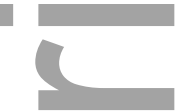

Analyst Coverage
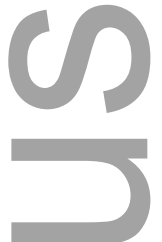

Collateral
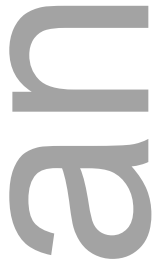

First Time Lead

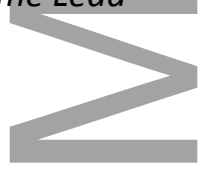

Interest Coverage

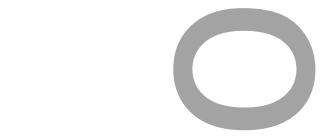

Lead Share

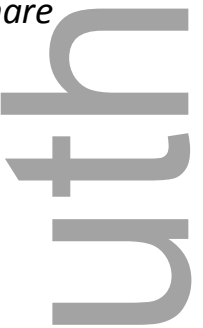

\section{Definition}

The natural logarithm of the loan amount in US dollars. (DealScan).

An indicator variable equal to 1 if there are any analysts following the firm in the month prior to the loan issuance date, 0 otherwise (I/B/E/S).

An indicator equal to 1 if the loan is secured, 0 otherwise. (DealScan).

An indicator variable equal to 1 if the lender serves as the lead arranger for the first time, 0 otherwise (DealScan).

Earnings before interest and tax divided by the interest expense, estimated in the quarter preceding a loan's issuance (Compustat).

The share of the loan held by the lead arranger, expressed in percentages (DealScan).

This is the author manuscript accepted for publication and has undergone full peer review but has not been through the copyediting, typesetting, pagination and proofreading process, which may lead to differences between this version and the Version of Record. Please cite this article as doi: 10.1111/1475-679X.12131.

This article is protected by copyright. All rights reserved. 
Leverage
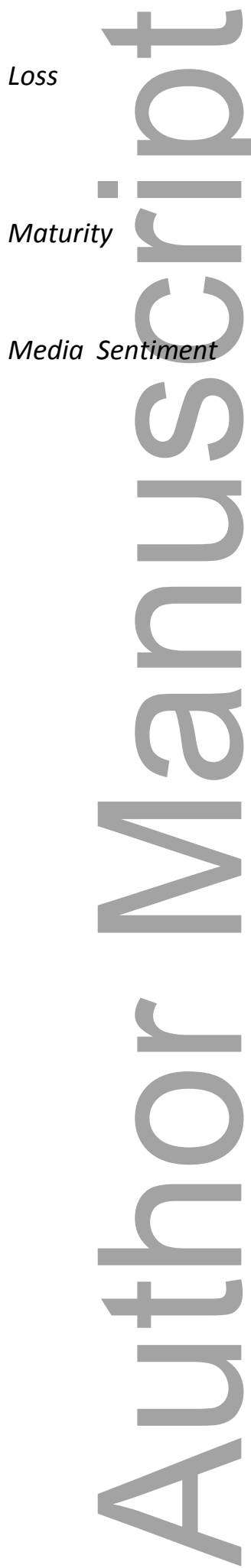

Total liabilities divided by total assets, estimated in the quarter preceding a loan's issuance (Compustat).

An indicator variable equal to 1 if ROA is less than zero, 0 otherwise (Compustat).

The number of months to maturity (DealScan).

The average Composite Sentiment Score (CSS) over the 180 day period prior to a loan's issuance date for full-size articles, conditional on the article's relevance score above 75 . Firm-initiated press releases are excluded from this estimation. CSS combines 5 sentiment scores (PEQ, BEE, BMQ, BCA, and $B A M)$, while insuring that there is no sentiment disagreement amongst these scores. The PEQ score represents the news sentiment of the given news item according to the PEQ classifier, which specializes in identifying positive and negative words and phrases in articles about global equities. The BEE score represents the news sentiment of a given story according to the BEE classifier, which specializes in news stories about earnings evaluations. The $\mathrm{BMQ}$ score represents the news sentiment of a given story according to the BMQ classifier, which specializes in short commentary and editorials on global equity markets. The BCA score represents the news sentiment of a given news story according to the BCA classifier, which specializes in reports on corporate action announcements. The BAM score represents the news sentiment of a given story according to the BAM classifier, which specializes in news stories about mergers, acquisitions and takeovers.

CSS scores range from 0 to 100 , with a score above 50 indicating positive news sentiment; equal to 50 , neutral news sentiment; and below 50 , negative news sentiment. We apply a linear transformation to the CSS score and define Media Content $=($ CSS-50) $/ 50$, so that the Media Content ranges from -1 to 1 , with zero being equivalent to neutral sentiment (RavenPack). 


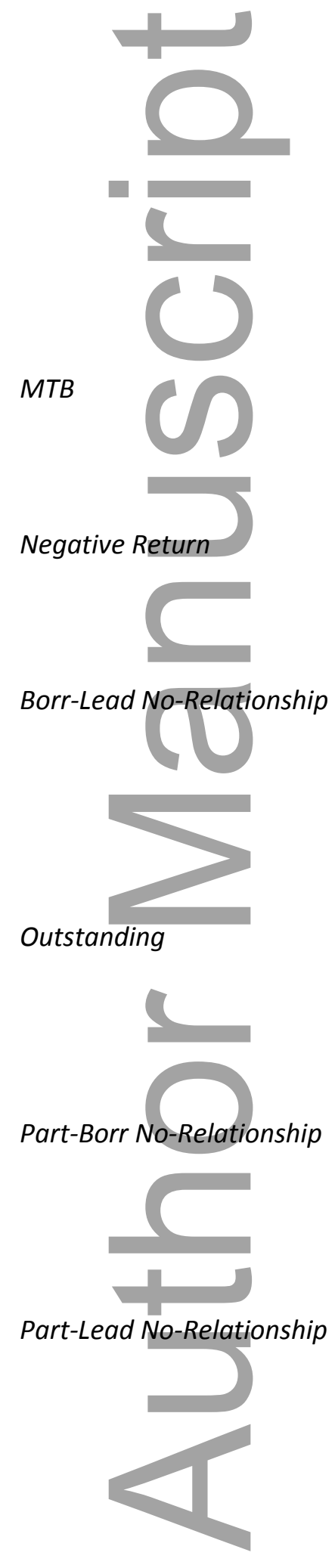

The market value of equity divided by the book value of equity, estimated in the quarter preceding a loan's issuance (Compustat).

An indicator variable equal to 1 if Return is less than zero, 0 otherwise (CRSP).

An indicator variable equal to 1 if a loan's lead arranger has syndicated less than 50 percent of a borrower's prior loan deals by volume over the five year period preceding the loan issuance date, 0 otherwise (DealScan).

An indicator variable equal to 1 if the borrower's previous deals are still outstanding at the current loan's issuance date, 0 otherwise (DealScan).

An indicator variable equal to 1 if the participant has not been involved in a deal with the borrower over the five year period preceding the loan issuance date, 0 otherwise (DealScan).

An indicator variable equal to 1 if the participant has not been involved in a deal with the lead arranger over the five year period preceding the loan issuance date, 0 otherwise (DealScan).

The average of the Current Outlook variable over the 180 day period prior to a loan's issuance data. Current Outlook is equal to -1 (1) if a borrower is on a negative or developing (positive) credit outlook at a loan's issuance date. The variable is equal to 0 if a borrower does not 
have either a positive or negative outlook at a loan's issuance date (S\&P historical database).
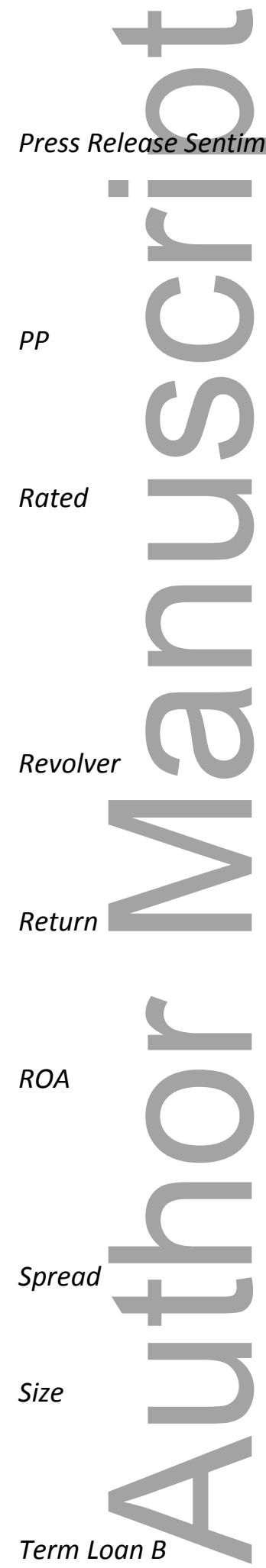

The average CSS for firm-initiated press releases with a relevance score greater than 90 , estimated over the 180 day period prior to a loan's issuance date (RavenPack).

An indicator variable equal to 1 if the loan has a performance pricing provision, 0 otherwise (DealScan).

An indicator variable equal to 1 if the borrower has a senior debt rating from S\&P, Moody's or Fitch, zero otherwise (DealScan and S\&P historical database).

An indicator variable equal to 1 if the loan is a revolving line of credit, 0 otherwise (DealScan).

The firm's market-adjusted (value-weighted) cumulative return over the 180 day period prior to a loan's issuance date.

Return on assets, defined as earnings before extraordinary items divided by total assets and estimated in the quarter preceding a loan's issuance (Compustat).

The natural logarithm of the loan spread over LIBOR (DealScan).

The natural logarithm of total assets, estimated in the quarter preceding a loan's issuance (Compustat).

An indicator variable equal to 1 if the loan type is Term loan $B$ or below (C, D, E and F), 0 otherwise (DealScan). 
An indicator variable equal to 1 if the change in bank lending standards for mid-sized and large commercial loans, as reported in

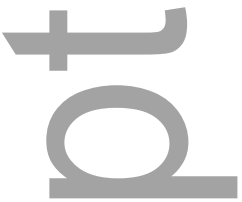

$\square$

Time-Between
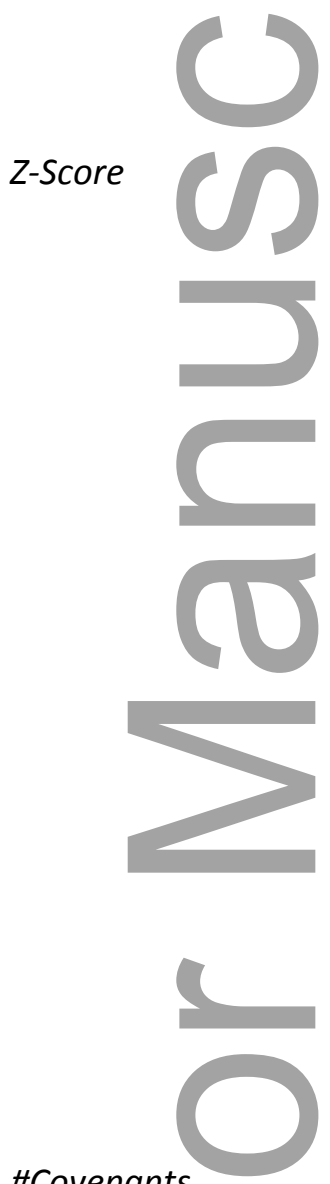

\#Covenants

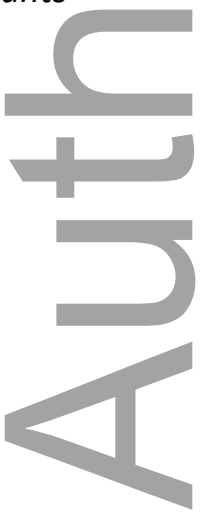
the Federal Reserve Board's quarterly Senior Loan Officer Opinion Survey on Bank Lending Practices, in the quarter of a loan's origination is in the top quartile of the sample's distribution, and 0 otherwise.

The number of days between the loan's issuance date and the previous deal (DealScan).

Altman's (1968) bankruptcy measure, estimated by the following model:

$Z=1.2 X_{1}+1.4 X_{2}+3.3 X_{3}+0.6 X_{4}+0.999 X_{5}$

where $X_{1}$ is defined as working capital (total current asset minus total current liabilities) divided by total assets. $X_{2}$ is defined as retained earnings divided by total assets. $X_{3}$ is defined as earnings before interest and taxes divided by total assets. $X_{4}$ is the market value of equity divided by total liabilities. $X_{5}$ is total sales divided by total assets. All measures are estimated in the quarter preceding a loan's issuance (Compustat).

The number of financial covenants (DealScan). 
Table 1 - Sample Selection

This table presents the sample selection process.
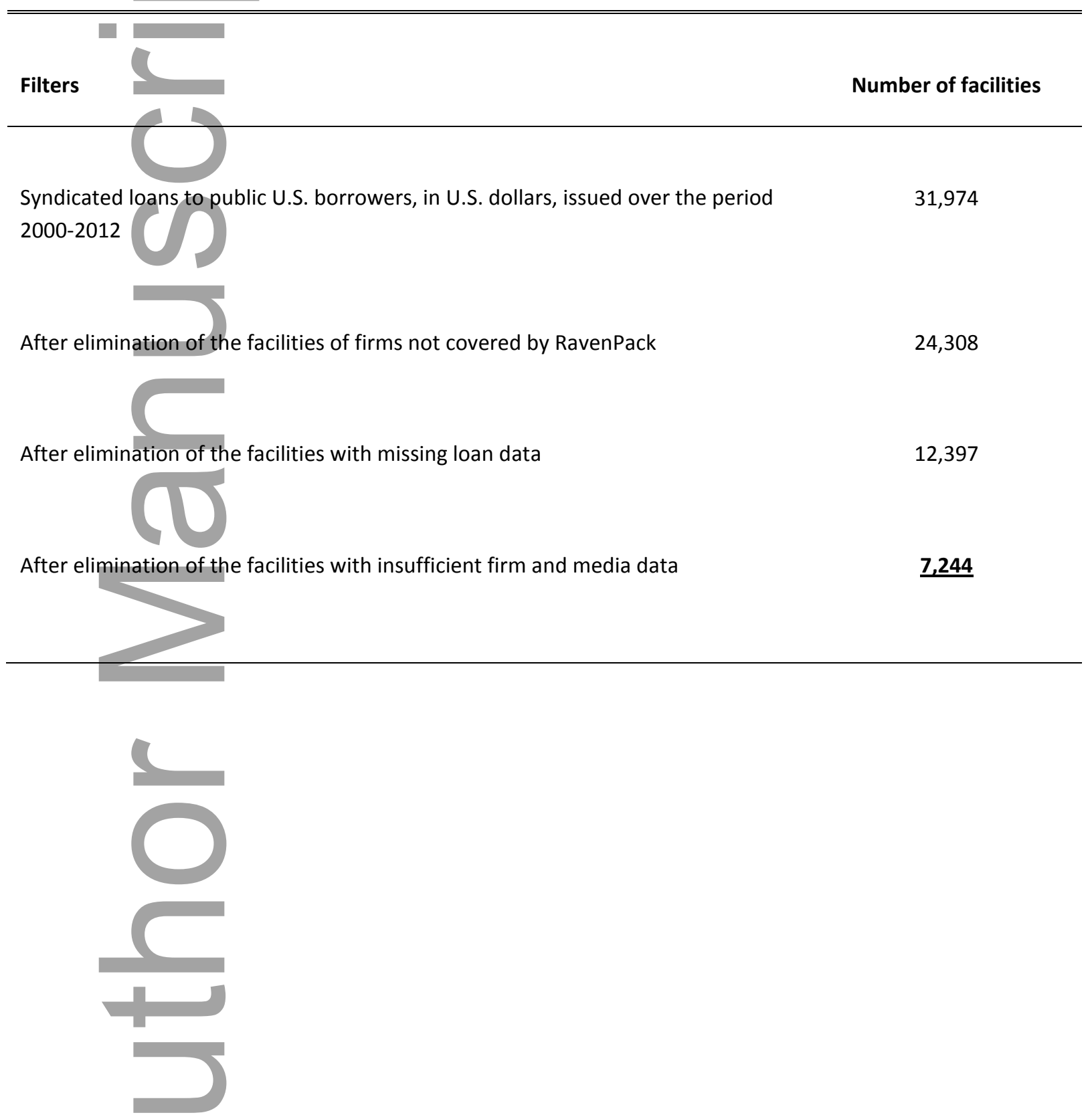

This is the author manuscript accepted for publication and has undergone full peer review but has not been through the copyediting, typesetting, pagination and proofreading process, which may lead to differences between this version and the Version of Record. Please cite this article as doi: 10.1111/1475-679X.12131.

This article is protected by copyright. All rights reserved. 
Table 2 - Descriptive Statistics

This table provides descriptive statistics (see Table 1 for the sample selection procedure). Variables are defined in Appendix A.

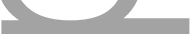

\begin{tabular}{|c|c|c|c|c|}
\hline Variable & $\mathbf{N}$ & Mean & Median & StdDev \\
\hline \multicolumn{5}{|l|}{ Media } \\
\hline Media Ser & 6,964 & -0.0046 & 0.0000 & 0.0386 \\
\hline \multicolumn{5}{|l|}{ Primary Loan Characteristics } \\
\hline Borr-Lead No-Relationship & 7,255 & 0.6379 & 1.0000 & 0.4806 \\
\hline Part-Borr N & 60,082 & 0.5675 & 0.0000 & 0.4954 \\
\hline Part-Lead No-Relationship & 60,082 & 0.1525 & 1.0000 & 0.3595 \\
\hline Lead Shar & 4,613 & 21.0525 & 13.3750 & 20.4714 \\
\hline Spread & 6,964 & 5.0720 & 5.1648 & 0.7221 \\
\hline \multicolumn{5}{|l|}{ Firm Characteristics } \\
\hline$R O A$ & 6,964 & 0.0085 & 0.0102 & 0.0253 \\
\hline Interest Coverage & 6,964 & 10.5052 & 2.1228 & 40.9157 \\
\hline Leverage & 6,964 & 0.2520 & 0.2373 & 0.1789 \\
\hline Size & 6,964 & 7.2521 & 7.2688 & 1.6609 \\
\hline Z-Score & 6,964 & 2.2403 & 1.6907 & 2.2198 \\
\hline MTB & 6,964 & 3.0102 & 2.0201 & 3.7461 \\
\hline Loss & 6,964 & 0.1476 & 0.0000 & 0.3547 \\
\hline \multicolumn{5}{|c|}{ Additional Loan Characteristics } \\
\hline Amount & 6,964 & 18.9334 & 19.1138 & 1.4854 \\
\hline Maturity & 6,964 & 47.9482 & 57.0000 & 21.4141 \\
\hline$P P$ & 6,964 & 0.7143 & 1.0000 & 0.4519 \\
\hline Collateral & 6,964 & 0.6392 & 1.0000 & 0.4802 \\
\hline
\end{tabular}




\begin{tabular}{lllll}
\hline \hline \#Covenants & 6,964 & 2.3109 & 2.0000 & 1.0131 \\
Revolver & 6,964 & 0.6229 & 1.0000 & 0.4846 \\
Term Loan B & 6,964 & 0.1002 & 0.0000 & 0.3006 \\
$\begin{array}{l}\text { Additional Information sources } \\
\text { Press Release Sentiment }\end{array}$ & 6,964 & 0.0243 & 0.0264 & 0.0287 \\
Rated & 6,964 & 0.5595 & 1.0000 & 0.4964 \\
Analyst Coverage & 6,964 & 0.8751 & 1.0000 & 0.3307 \\
Returns & & & & \\
Return & 6,964 & 0.0558 & 0.0216 & 0.3121 \\
Negative Return & 6,964 & 0.4275 & 0.0000 & 0.4947 \\
& & & & \\
\end{tabular}
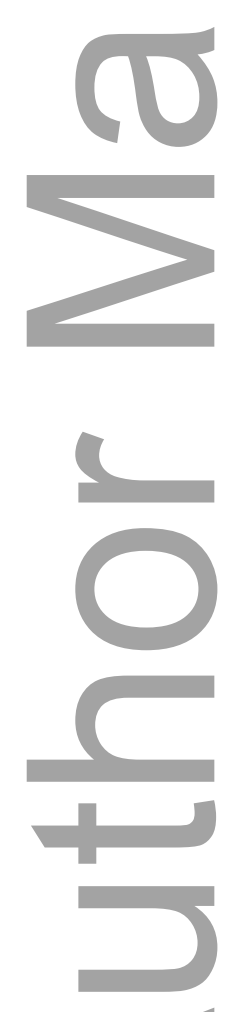

Table 3 - Media Sentiment and the Probability of a Non-Relationship Lead Arranger 
This table presents the analysis of the effect of media sentiment on the probability of a non-relationship lender serving as a loan's lead arranger. $* * *, * *, *$ indicate significance at the $0.01,0.05,0.10$ levels, respectively. All variables are defined in Appendix A.

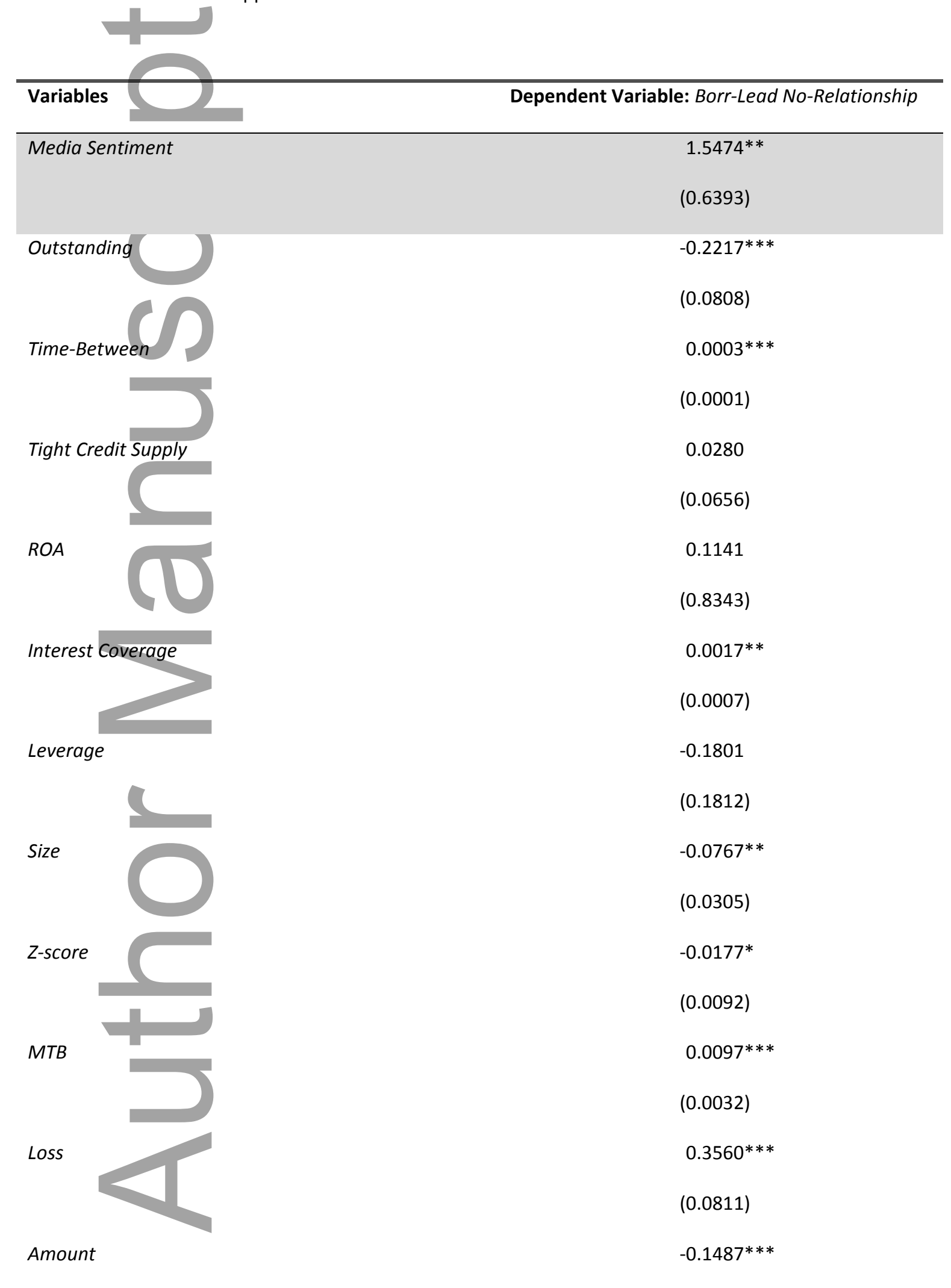




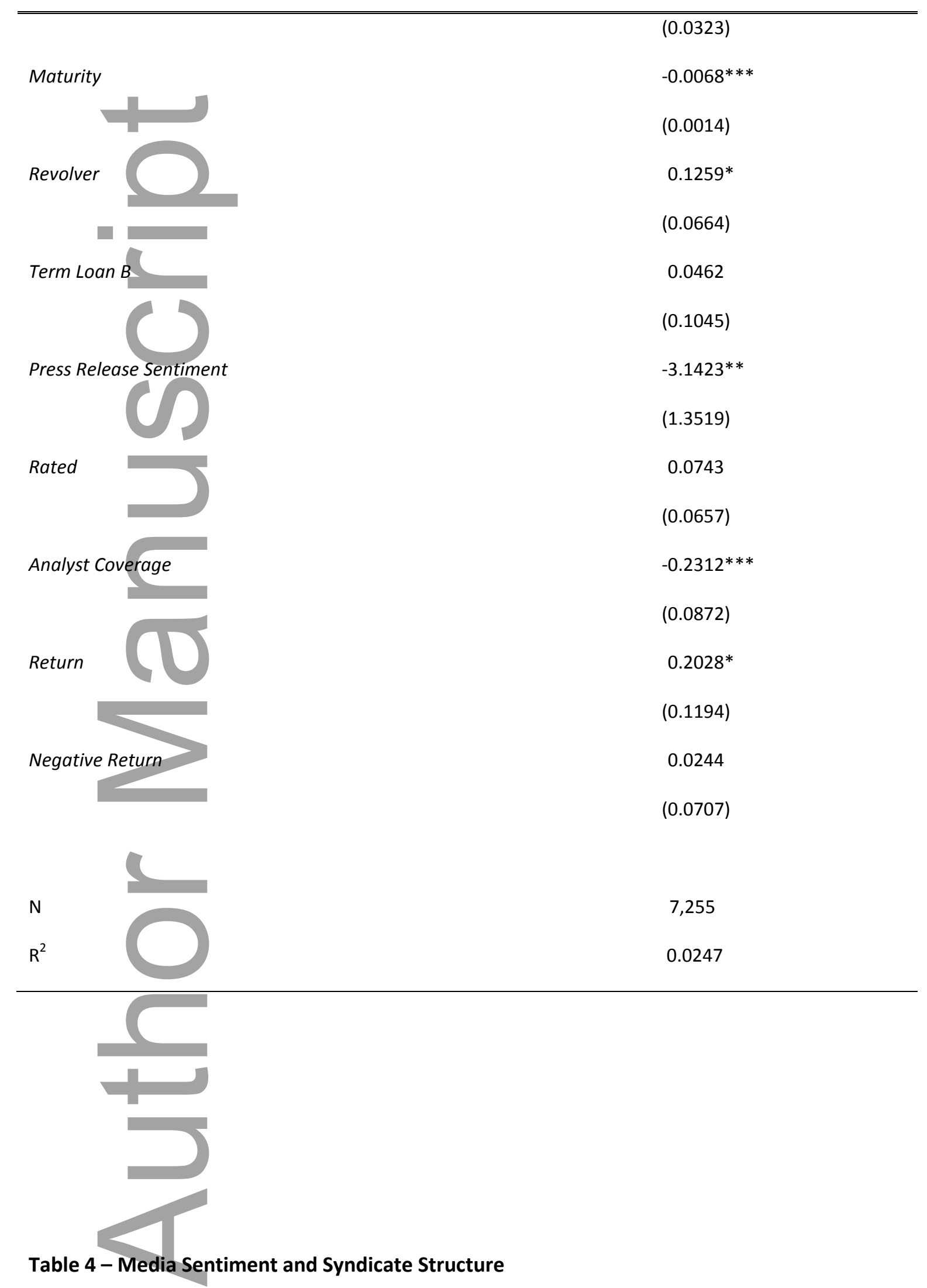


The table presents the analyses of the effects of media sentiment on the characteristics of the syndicate's structure. Column 1 (2) presents the analysis of the variable reflecting a participant's prior relationship with the borrower (the lead arranger), while column 3 presents the analysis of the loan share retained by the lead arranger. $* * *, * *, *$ indicates significance at the $0.01,0.05,0.10$ level, respectively. All variables are defined in Appendix A.

\begin{tabular}{|c|c|c|c|}
\hline \multirow{3}{*}{ Variable } & \multicolumn{3}{|c|}{ Dependent Variable } \\
\hline & Part-Borr & Part-Lead & Lead Share \\
\hline & No-Relationship & No-Relationship & \\
\hline \multirow[t]{2}{*}{ Media Sentiment } & $1.7654^{* *}$ & $2.3114^{* *}$ & $-28.7105^{* * *}$ \\
\hline & (0.7714) & (1.1204) & (6.8194) \\
\hline \multirow[t]{2}{*}{$R O A$} & $3.2091^{*}$ & -0.9517 & $-101.6974 * * *$ \\
\hline & $(1.6573)$ & $(2.3441)$ & $(24.5548)$ \\
\hline \multirow[t]{2}{*}{ Interest Coverage } & $0.0026^{* *}$ & 0.0017 & 0.0013 \\
\hline & $(0.0011)$ & $(0.0014)$ & (0.0158) \\
\hline \multirow[t]{2}{*}{ Leverage } & $-0.4195^{* *}$ & 0.4476 & $-6.2121 *$ \\
\hline & $(0.1925)$ & $(0.3423)$ & $(3.5286)$ \\
\hline \multirow[t]{2}{*}{ Size } & $-0.1409 * * *$ & -0.0646 & $-2.2487 * * *$ \\
\hline & $(0.0301)$ & $(0.0490)$ & $(0.6833)$ \\
\hline \multirow[t]{2}{*}{ Z-score } & $0.0641^{* * *}$ & -0.0190 & 0.1689 \\
\hline & $(0.0192)$ & $(0.0301)$ & $(0.3279)$ \\
\hline \multirow[t]{2}{*}{ MTB } & -0.0001 & $-0.0155^{*}$ & -0.0041 \\
\hline & $(0.0061)$ & $(0.0092)$ & $(0.1061)$ \\
\hline \multirow[t]{2}{*}{ Loss } & 0.1358 & 0.1263 & 0.5926 \\
\hline & $(0.0833)$ & $(0.1217)$ & $(1.3263)$ \\
\hline \multirow[t]{2}{*}{ Amount } & 0.0196 & -0.0358 & $-5.9624 * * *$ \\
\hline & $(0.0256)$ & $(0.0419)$ & $(0.6365)$ \\
\hline \multirow[t]{2}{*}{ Maturity } & $0.0050 * * *$ & $-0.0041 * *$ & $-0.1084 * * *$ \\
\hline & $(0.0011)$ & (0.0019) & $(0.0329)$ \\
\hline \multirow[t]{2}{*}{ Spread } & $0.3591 * * *$ & $0.2945^{* * *}$ & 0.1706 \\
\hline & $(0.0343)$ & $(0.0696)$ & $(1.0446)$ \\
\hline Collateral & $0.1044 *$ & 0.0119 & -0.2789 \\
\hline
\end{tabular}




\begin{tabular}{|c|c|c|c|}
\hline & $(0.0603)$ & $(0.0896)$ & $(1.1808)$ \\
\hline \multirow[t]{2}{*}{$P P$} & $0.2208^{* * *}$ & -0.0365 & $-7.8570 * * *$ \\
\hline & $(0.0543)$ & $(0.0896)$ & (1.7009) \\
\hline \multirow[t]{2}{*}{ \#Covenants } & 0.0377 & $0.1479 * * *$ & $-0.9175^{*}$ \\
\hline & $(0.0287)$ & $(0.0424)$ & $(0.5226)$ \\
\hline \multirow[t]{2}{*}{ Revolver } & $-0.2142 * * *$ & $-0.1186 * *$ & 1.0176 \\
\hline & $(0.0362)$ & $(0.0605)$ & (0.9951) \\
\hline \multirow[t]{2}{*}{ Term Loan B } & $0.2446 * * *$ & $0.5395^{* * *}$ & $15.4806^{* * *}$ \\
\hline & $(0.0832)$ & $(0.1224)$ & $(2.2275)$ \\
\hline \multirow[t]{2}{*}{ Borr-Lead No-Relationship } & $0.4786^{* * *}$ & $0.5447^{* * *}$ & $2.2707 * * *$ \\
\hline & $(0.0440)$ & $(0.0750)$ & $(0.4899)$ \\
\hline \multirow[t]{2}{*}{ First Time Lead } & 0.1061 & $1.7979 * * *$ & $4.8580 *$ \\
\hline & $(0.1577)$ & $(0.3378)$ & $(2.7667)$ \\
\hline \multirow[t]{2}{*}{ Press Release Sentiment } & 0.0181 & -0.6315 & 13.6202 \\
\hline & $(0.7750)$ & $(1.2702)$ & $(16.4236)$ \\
\hline \multirow[t]{2}{*}{ Rated } & $0.1824 * * *$ & 0.1268 & $-2.0909^{*}$ \\
\hline & $(0.0662)$ & $(0.0986)$ & $(1.1038)$ \\
\hline \multirow[t]{2}{*}{ Analyst Coverage } & 0.0117 & -0.1215 & $-5.0446 * *$ \\
\hline & $(0.0910)$ & (0.1569) & $(2.1421)$ \\
\hline \multirow[t]{2}{*}{ Return } & $0.3726 * * *$ & $0.3464 * *$ & $-2.7937^{*}$ \\
\hline & (0.1203) & $(0.1755)$ & $(1.4571)$ \\
\hline \multirow[t]{2}{*}{ Negative Return } & $0.2131^{* * *}$ & 0.1245 & 0.4680 \\
\hline & $(0.0616)$ & $(0.0994)$ & $(0.7463)$ \\
\hline Model & Logit & Logit & OLS \\
\hline \multirow[t]{2}{*}{ Fixed Effects } & None & None & Year/Industry/ \\
\hline & & & Purpose \\
\hline$N$ & 60,082 & 60,082 & 4,613 \\
\hline$R^{2}$ & 0.0561 & 0.0620 & 0.4900 \\
\hline
\end{tabular}




\section{Table 5 - Media Sentiment and Interest Rate Spread}

This table presents the analysis of the effects of media sentiment on the interest spread. ${ }^{* * *},{ }^{* *}, *$ indicates significance at the $0.01,0.05,0.10$ level, respectively. All variables are defined in Appendix A.

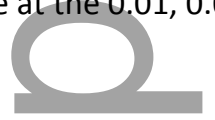

\begin{tabular}{|c|c|}
\hline Variable & Dependent Variable: Spread \\
\hline Media Sentiment & $\begin{array}{l}-1.0930 * * * \\
(0.2479)\end{array}$ \\
\hline$R O A$ & $\begin{array}{l}-1.3283^{* * *} \\
(0.3475)\end{array}$ \\
\hline Interest Coverage & $\begin{array}{l}0.0000 \\
(0.0000)\end{array}$ \\
\hline Leverage & $\begin{array}{l}0.4288^{* * *} \\
(0.0581)\end{array}$ \\
\hline Size & $\begin{array}{l}-0.0396 * * * \\
(0.0106)\end{array}$ \\
\hline Z-score & $\begin{array}{l}-0.0078^{* *} \\
(0.0035)\end{array}$ \\
\hline MTB & $\begin{array}{l}-0.0076^{* *} \\
(0.0030)\end{array}$ \\
\hline Loss & $\begin{array}{l}0.1287^{* * *} \\
(0.0236)\end{array}$ \\
\hline Amount & $\begin{array}{l}-0.0676^{* * *} \\
(0.0078)\end{array}$ \\
\hline Maturity & $\begin{array}{l}-0.0004 \\
(0.0004)\end{array}$ \\
\hline Collateral & $\begin{array}{l}0.5123^{* * *} \\
(0.0252)\end{array}$ \\
\hline
\end{tabular}


(0.0192)

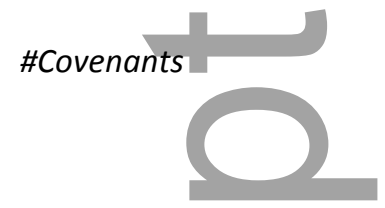

$0.0939 * * *$

(0.0085)

Revolver

$-0.0733^{* * *}$

(0.0157)

Term Loan B

$0.1725^{* * *}$

(0.0258)

Press Release Sentiment

$-0.9077 * * *$

(0.2519)

Rated

$-0.0021$

$(0.0235)$

Analyst Coverage

$-0.0607^{* * *}$

$(0.0218)$

Return

$0.0800 * * *$

(0.0294)

Negative Return

$0.0314 * *$

$(0.0155)$

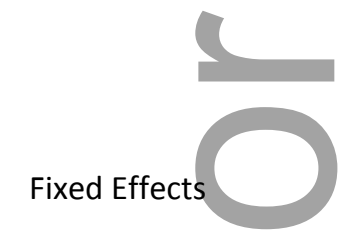

Year/Industry/Purpose

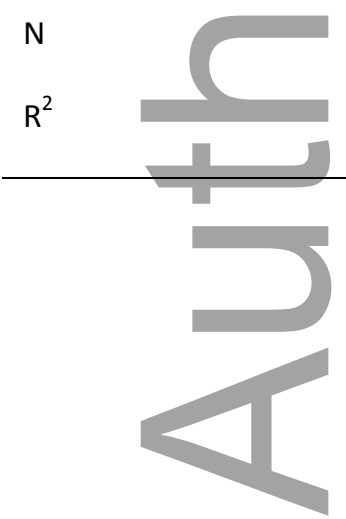

6,964

0.6697

Table 6 - The Effect of Media Sentiment Conditional on Intensity of Analysts' Coverage 
This table presents the analysis of the effects of media sentiment on the probability of a non-relationship lender serving as a loan's lead arranger (Borr-Lead No-Relationship), the probability of a participant's prior relationship with the borrower (Part-Borr No-Relationship), the probability of a participant's prior relationship with the lead arranger (Part-Lead No-Relationship), the loan share retained by the lead arranger (Lead Share) and the interest spread (Spread), conditional on equity analysts' coverage intensity. ${ }^{* * *}, * *,{ }^{*}$ indicates significance at the $0.01,0.05,0.10$ level respectively. \#\#\#, \#\#, \# indicates that the difference across analyst coverage partitions is significant at the $0.01,0.05$ and 0.10 level respectively. All variables are defined in Appendix A.

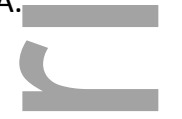

Panel A: The probability of a non-relationship lead arranger, conditional on analyst coverage intensity

Dependent Variable: Borr-Lead No-Relationship

\begin{tabular}{lcc}
\cline { 2 - 3 } Variable & Less Intensive Coverage & Highly Intensive Coverage \\
\hline Media Sentiment & $1.8891^{* *}$ & 0.5731 \\
& $(1.081)$ & $(1.951)$ \\
Model & Logit & Logit \\
Controls & Included & Included \\
$\mathrm{N}$ & 5,268 & 1,987 \\
$\mathrm{R}^{2}$ & 0.0402 & 0.0848
\end{tabular}

Panel B: The syndicate participation of lenders without a prior relationship with the borrower, conditional on analyst coverage intensity

\begin{tabular}{lcc} 
& \multicolumn{2}{c}{ Dependent Variable: Part-Borr No-Relationship } \\
\cline { 2 - 3 } Variable & Less Intensive Coverage & Highly Intensive Coverage \\
\hline Media Sentiment & $(0.908)^{*} \# \#$ & -1.3446 \\
& & $(1.693)$ \\
Model & Logit & Logit \\
Controls & Included & Included
\end{tabular}




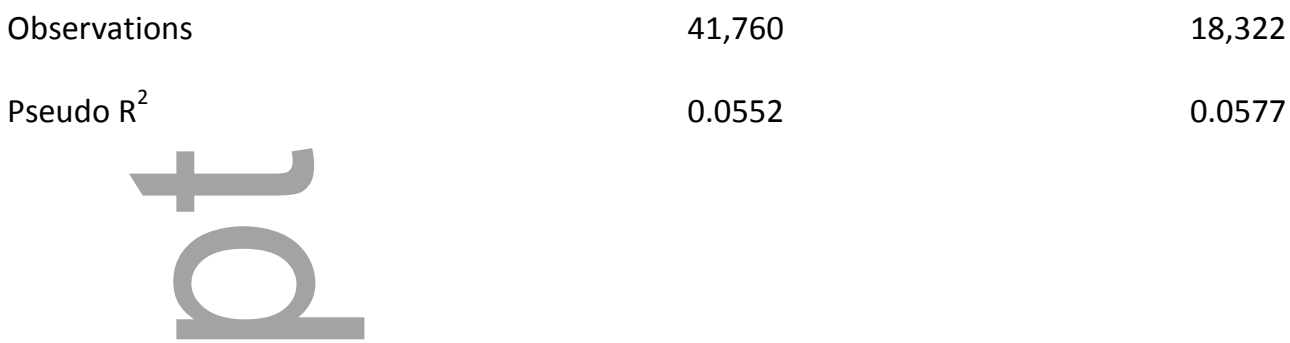

Panel C: The syndicate participation of lenders without a prior relationship with the lead arranger, conditional on analyst coverage intensity

Dependent Variable: Part-Lead No-Relationship

Variable

Less Intensive Coverage

Highly Intensive Coverage

\begin{tabular}{lcc}
\hline Media Sentiment & $2.9520^{* *}$ & 0.6063 \\
& $(1.259) \# \#$ & $(1.764)$ \\
Model & Logit & Logit \\
Controls & Included & Included \\
Observations & 41,760 & 18,322 \\
Pseudo R & & 0.0529
\end{tabular}

Panel D: The loan share retained by the lead arranger, conditional on analyst coverage intensity

Dependent Variable: Lead Share

\begin{tabular}{lcc}
\cline { 2 - 3 } Variable & Less Intensive Coverage & Highly Intensive Coverage \\
\hline Media Sentiment & $-25.175^{* * *}$ & -10.1900 \\
& $(8.131) \#$ & $(20.378)$ \\
Model & OLS & OLS \\
Controls & Included & Included \\
Fixed Effects & Year/Industry/Purpose & Year/Industry/Purpose \\
Observations & 3,108 & 1,505 \\
$\mathrm{R}^{2}$ & 0.4646 & 0.6451
\end{tabular}


Panel E: Loan pricing, conditional on analyst coverage intensity

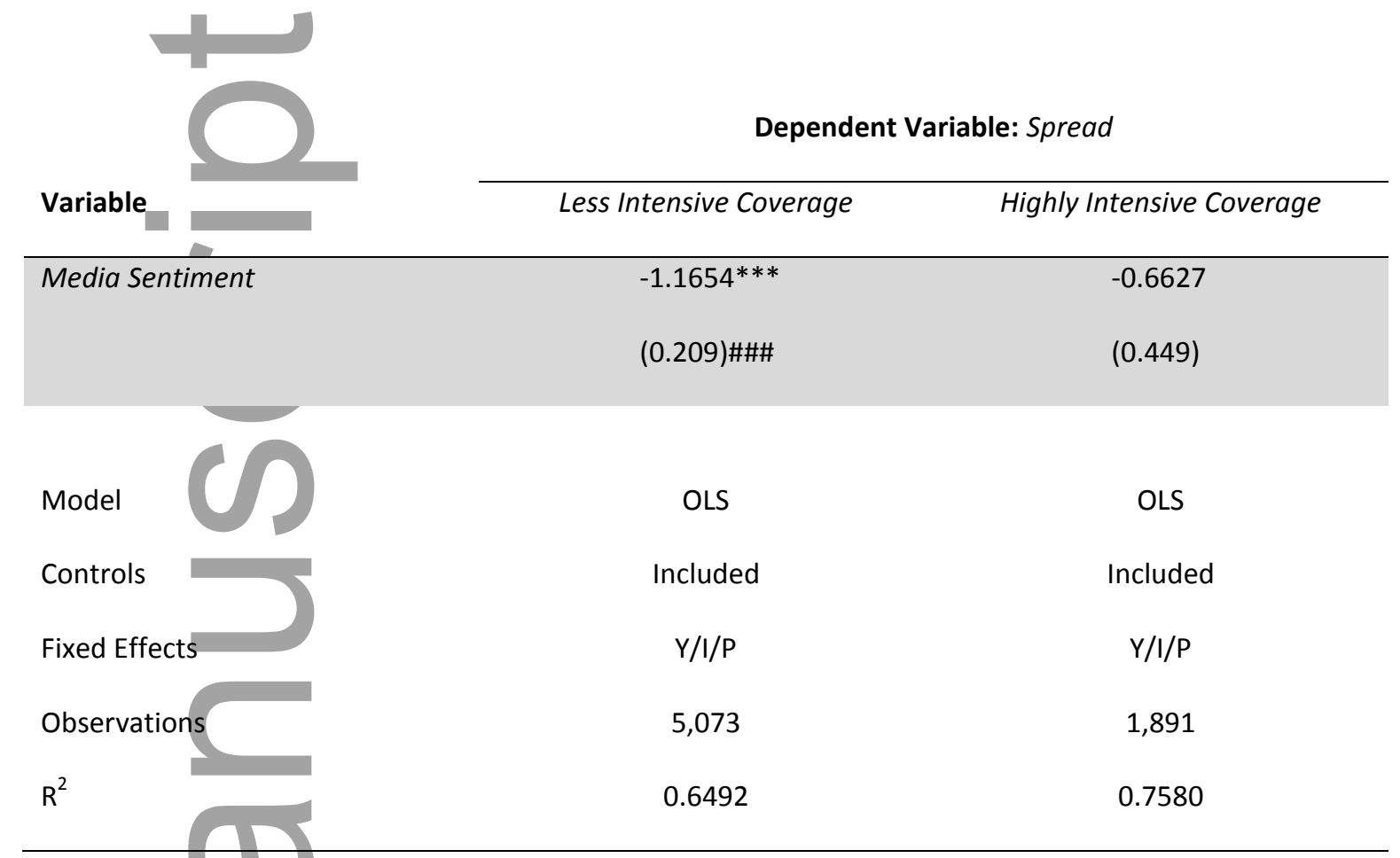
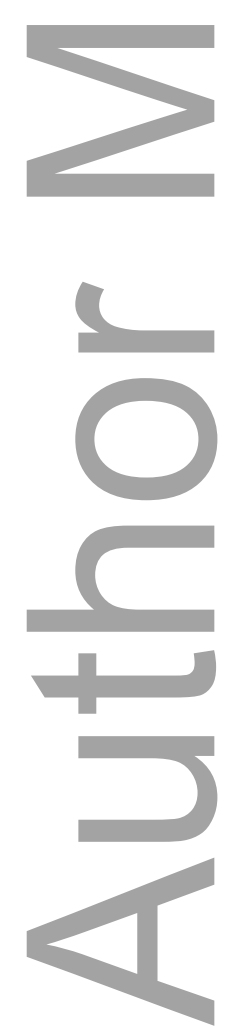

Table 7 - The Effect of Media Sentiment Conditional on Analyst Coverage Reduction 
This table presents the analysis of the effects of media sentiment on the probability of a non-relationship lender serving as a loan's lead arranger (Borr-Lead No-Relationship), the probability of a participant's prior relationship with the borrower (Part-Borr No-Relationship), the probability of a participant's prior relationship with the lead arranger (Part-Lead No-Relationship), the loan share retained by the lead arranger (Lead Share) and the interest spread (Spread), conditional on equity analysts' coverage reduction. $* * *, * *, *$ indicates significance at the $0.01,0.05,0.10$ level respectively. \#\#, \#\#, \# indicates that the difference across analyst coverage partitions is significant at the $0.01,0.05$ and 0.10 level respectively. All variables are defined in Appendix A.

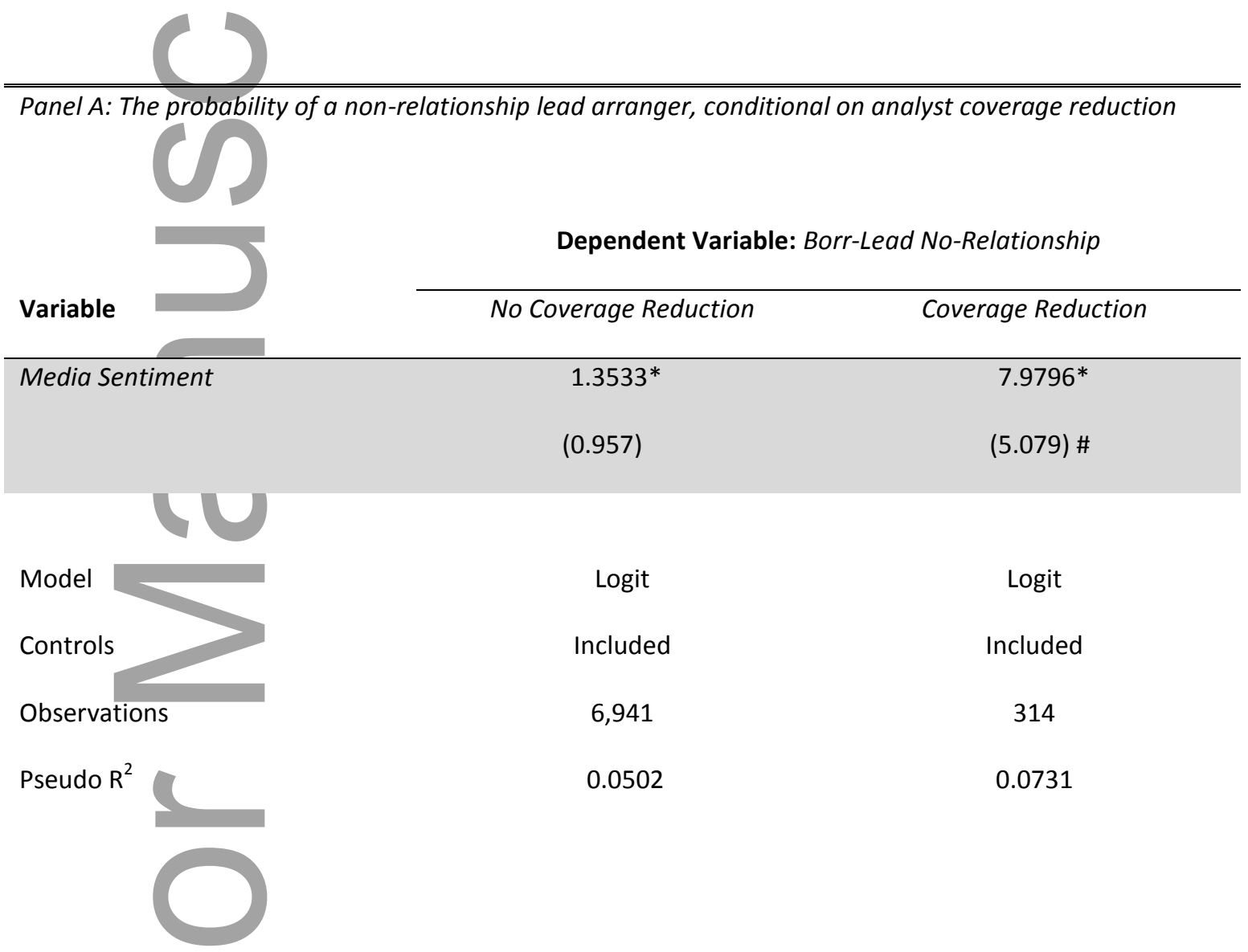

Panel B: The syndicate participation of lenders without a prior relationship with the borrower, conditional on analyst coverage reduction

\begin{tabular}{lcc} 
& \multicolumn{2}{c}{ Dependent Variable: Part-Borr No-Relationship } \\
\cline { 2 - 3 } Variable & $1.6771^{* *}$ & Coverage Reduction \\
\hline Media Sentiment & $(0.796)$ & $(2.640) \#$ \\
Model & & \\
& Logit & Logit \\
\hline
\end{tabular}



Controls
Included
Included
Observations
56,274
3,807
Pseudo $\mathrm{R}^{2}$
0.0571
0.0835

Panel C: The syndicate participation of lenders without a prior relationship with the lead arranger, conditional on analyst coverage reduction

Dependent Variable: Part-Lead No-Relationship

\begin{tabular}{lcc} 
Variable & No Coverage Reduction & Coverage Reduction \\
\hline Media Sentiment & $2.4008^{* *}$ & 0.6238 \\
& $(1.155)$ & $(3.920)$ \\
Model & Logit & Logit \\
Controls & Included & Included \\
Observations & 56,274 & 3,807 \\
Pseudo $\mathrm{R}^{2}$ & 0.0613 & 0.0873 \\
\hline \hline
\end{tabular}

Panel D: The loan share retained by the lead arranger, conditional on analyst coverage reduction

\begin{tabular}{|c|c|c|}
\hline \multirow[b]{2}{*}{ Variable } & \multicolumn{2}{|c|}{ Dependent Variable: Lead Share } \\
\hline & No Coverage Reduction & Coverage Reduction \\
\hline Media Sentiment & $\begin{array}{c}-25.7339 * * * \\
(7.144)\end{array}$ & $\begin{array}{l}-35.0953 \\
(52.041)\end{array}$ \\
\hline Model & OLS & OLS \\
\hline Controls & Included & Included \\
\hline Fixed Effects & Year/Industry/Purpose & Year/Industry/Purpose \\
\hline Observations & 4,417 & 196 \\
\hline$R^{2}$ & 0.4890 & 0.7396 \\
\hline
\end{tabular}


Panel E: Loan pricing, conditional on analyst coverage reduction

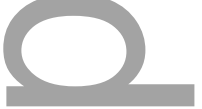

\begin{tabular}{lcc} 
& \multicolumn{2}{c}{ Dependent Variable: Spread } \\
\cline { 2 - 3 } Variable & $-1.1771^{* * *}$ & \multicolumn{2}{c}{ Coverage Reduction } \\
\hline Media Sentiment & $(0.206)$ & $(1.396) \# \#$ \\
& & \\
Model & OLS & OLS \\
Controls & Included & Included \\
Fixed Effects & Year/Industry/Purpose & 310 \\
Observations & 6,654 & Year/Industry/Purpose \\
$\mathrm{R}^{2}$ & 0.6619 & 0.8496 \\
\hline
\end{tabular}
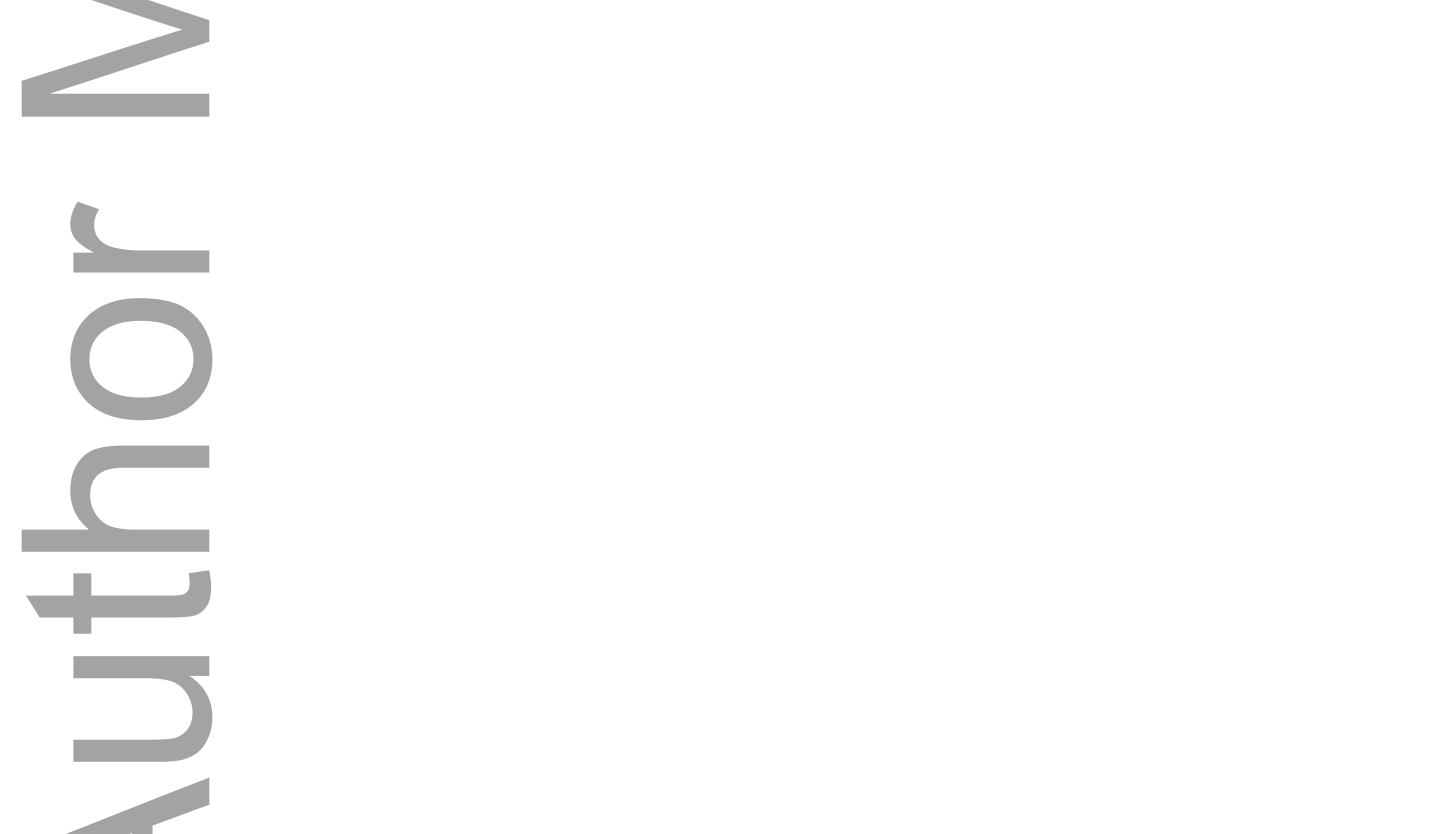

Table 8 - The Effect of Media Content on Loan Pricing, Conditional on a Borrower's ConsumerProduct Intensity 
This table presents the analysis of the effects of media sentiment on the interest spread, conditional on a borrower's consumer-product intensity. $* * *, * *, *$ indicates significance at the $0.01,0.05,0.10$ level respectively. \#\#\#, \#\#, \# indicates that the difference across consumer-product intensity partitions is significant at the $0.01,0.05$ and 0.10 level respectively. All variables are defined in Appendix A.

\begin{tabular}{lcc}
\hline & Dependent Variable: Spread \\
\hline Variable & Low Intensity & High Intensity \\
\hline Media Sentiment & $-0.636^{* *}$ & (0.327) \\
Model & OLS & OLS \\
Controls & Included & Included \\
Fixed Effects & Y/I/P & Y/I/P \\
$\mathrm{N}$ & 3,357 & 3,429 \\
$\mathrm{R}^{2}$ & 0.6580 & 0.7107 \\
\hline
\end{tabular}

